\title{
Work and Occupations http://wox.sagepub.com/
}

\section{Stagnating Industrial Employment in Latin America}

David Brady, Yunus Kaya and Gary Gereffi

Work and Occupations 2011 38: 179 originally published online 31 March 2011 DOI: $10.1177 / 0730888410387987$

The online version of this article can be found at: http://wox.sagepub.com/content/38/2/179

\author{
Published by: \\ (3)SAGE \\ http://www.sagepublications.com
}

Additional services and information for Work and Occupations can be found at:

Email Alerts: http://wox.sagepub.com/cgi/alerts

Subscriptions: http://wox.sagepub.com/subscriptions

Reprints: http://www.sagepub.com/journalsReprints.nav

Permissions: http://www.sagepub.com/journalsPermissions.nav

Citations: http://wox.sagepub.com/content/38/2/179.refs.html 


\title{
Stagnating Industrial Employment in Latin America
}

Work and Occupations

$38(2)$ 179-220

(C) The Author(s) 201 I

Reprints and permission: sagepub.com/journalsPermissions.nav DOI: 10.1 I 77/0730888410387987 http://wox.sagepub.com

๑SAGE

\author{
David Brady',Yunus Kaya², \\ and Gary Gereffi'
}

\begin{abstract}
The industrialization of developing countries has fundamentally transformed work, employment, and labor for millions. Despite the industrialization of most of the developing world, we present evidence that Latin America has experienced stagnating industrial employment in the past few decades. Benefiting from recently available data on industrial employment as a percentage of total employment from 1980 through 2006, we analyze fixed-effects models for 20 Latin American countries. Specifically, we examine three theoretical explanations: productivity/comparative advantage, institutionalism, and dependency/world-systems. Our analyses demonstrate that the prevailing productivity/comparative advantage explanation has limited value. By contrast, we find supportive evidence for a combination of institutional and dependency/world-systems variables. In particular, the stagnating industrial employment share in Latin American countries has been driven by the negative effects of (in order of magnitude) the Mercosur trade agreement, mineral and ore exports (as a percentage of total exports), the duration of the current political regime, military spending (as a percentage of GDP), and inward foreign direct investment flows (as a percentage of GDP).
\end{abstract}

\section{Keywords}

deindustrialization, manufacturing, industry, political economy, globalization

'Duke University, Durham, NC, USA

${ }^{2}$ University of North Carolina-Wilmington, NC, USA

\section{Corresponding Author:}

David Brady, Department of Sociology, Duke University, Box 90088, Durham, NC 27708

Email: brady@soc.duke.edu 


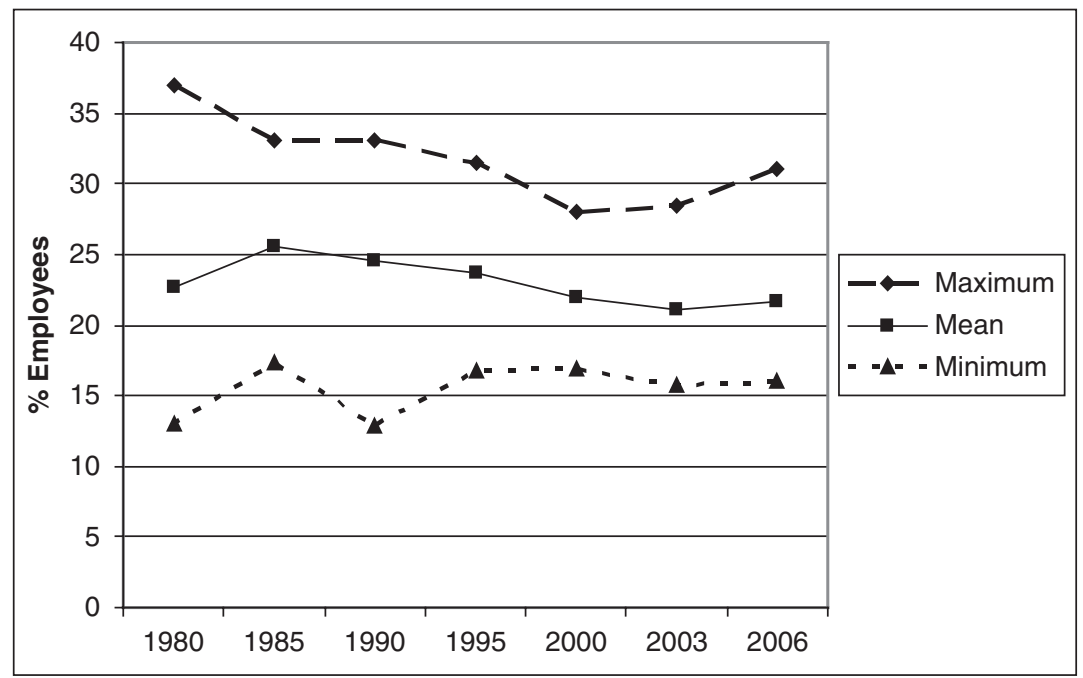

Figure I. Trends in industrial share of employment in 20 Latin American countries, 1980-2006

In recent decades, the developing world has experienced a surge of industrialization. As exemplified by East Asia's ascent, industrial employment has expanded considerably in many less developed countries (LDCs; Amsden, 2001). For example, in his analysis of 64 LDCs, Kaya (2010) shows that the average industrial employment share expanded from $15 \%$ to $22 \%$ from 1980 to 2003. This growth in industrial employment (as a percentage of total employment) has fundamentally transformed the work and employment of millions. Although many affluent democracies have experienced deindustrialization in recent decades, the industrialization of LDCs provides what Frieden (2006) calls "the success stories" and "supporting arguments for" (p. 434) the contemporary era of globalization (also Amsden, 2001; Firebaugh, 2003). In one of the most important developments in work over the past few decades, most of the world's workers have experienced growing industrial employment in their countries.

Yet among LDCs, at least one region stands out for paradoxically departing from this pattern. Since 1980, industrial employment as a percentage of total employment in Latin America appears to have stagnated. ${ }^{1}$ As Figure 1 reveals, the industrial share of the average Latin American country (of sample of 20 described below) rose from $22.7 \%$ in 1980 to $25.5 \%$ in 1985 and $24.5 \%$ in 1990. Since then, however, the mean fell to $21.0 \%$ in 2003 and $21.6 \%$ in 2006 . 
Although the mean industrial share of employment across the period (22.9) was higher than many LDCs, the trend has clearly departed from the industrialization experienced across the developing world. The bivariate correlation between the industrial share of employment and time is significantly negative $(r=-.21$; see Appendix A). Moreover, a fixed-effects (FE) model of the industrial share results in a significant negative effect of time $(t=-2.97)$. If we allow time to have a nonlinear relationship, an FE model shows that industrial employment did not change significantly from 1980 to 1995 . However, the coefficients of the dummy variables for 2000, 2003, and 2006 are significantly negative compared with the reference of 1995. On balance, it is difficult to declare that this trend is unequivocally one of decline. At the very least, however, the evidence suggests that the industrial employment share has stagnated in these 20 countries (see Appendix A). ${ }^{2}$

Of course, within this broad trend, there was substantial cross-country variation (see Appendix B). Some relatively more industrialized countries like Argentina, Colombia, and Trinidad and Tobago had average industrial shares above $26 \%$. Yet Figure 1 reveals that even the maximum value in the sample declined from $36.9 \%$ in 1980 (Trinidad and Tobago) to $31.5 \%$ in 1995 (Colombia) to a range from $28 \%$ to $31 \%$ after 2000 (Trinidad and Tobago). On balance, a few Latin American countries like Jamaica, Panama, and Nicaragua experienced growing industrial employment after 1980. Figure 1 shows that the minimum rose from $13 \%$ in 1980 (Nicaragua) to $16.7 \%$ in 1995 (Paraguay). However, even the minimum fell to about 16\% after 2003 (Paraguay). The most visible decline occurred in Colombia where the industrial share fell from $34 \%$ to $18.8 \%$ in 2006 . This was no anomaly, however. In all 20 Latin American countries in our sample, the industrial share of employment was lower in 2006 than it was at its peak (which varied across countries, see Appendix B). ${ }^{3}$

Whereas industrial employment stagnated, agricultural employment continued to decline. Most of the workers leaving agriculture and new entrants into the labor market experienced unemployment or were absorbed into the service sector as routine nonmanual workers or into the informal sector (ILO, 2010; Portes \& Hoffman, 2003; Portes \& Roberts, 2005). Meanwhile, employment in the public sector stagnated or declined (ILO, 2010). In addition, there is not much evidence suggesting a shift toward high-tech industries, which was the case in the newly industrialized East Asian countries (ILO, 2010).

Overall, the stagnation of industrial employment in these Latin America countries presents an important theoretical puzzle. Latin America is proximate to the richest and largest consumer market in the world. As the United States has deindustrialized and reduced its barriers to imports, these Latin American countries have had a comparative advantage in cheap labor. Across Latin America, the average worker productivity and skill level have risen just as 
technology for international communication and transportation has advanced. Over the past few decades, political stability in most of these countries has improved as well - producing a more attractive and secure market for investment. Given these changes and the industrialization of most other LDCs, one reasonably could have expected these Latin America countries to have experienced rising industrialization over the past few decades. Moreover, Latin American industrialization has long occupied the attention of scholars (Bairoch, 1975; Evans, 1979; Gereffi \& Wyman, 1990; Hirschman, 1958, 1968), and at least since Marx, industrialization has always been an orienting concern for scholars of work, employment, and labor.

The stagnating industrial employment of Latin American countries is also important because the lives of workers tend to improve with industrialization. In Latin America and elsewhere, the industrial share of employment has been historically positively associated with GDP per capita, life expectancy, secondary school enrollment, and democracy, and negatively associated with child mortality. Although industrialization is no panacea for LDCs and can be linked with social problems like inequality and pollution, it has generally improved the employment conditions of workers, resulting in higher pay and greater potential for labor mobilization. Therefore, the stagnation of industrial employment portends an important dilemma for the workers of these 20 Latin American countries.

This study assesses the evidence for three theoretical explanations of international variation in industrialization to explain the trends in the industrial employment share in 20 Latin American countries. We consider the evidence for what we call the "productivity and comparative advantage" explanation, which is the leading model in studies of industrialization and deindustrialization (Alderson, 1999; Brady \& Denniston, 2006). We then evaluate institutional sources of industrial employment. Last, we draw on arguments from worldsystems/dependency theory. ${ }^{4}$ Our analyses are based on FE models of recently available comparable data on the industrial share of employment in 20 Latin American countries from 1980 to 2006. Ultimately, we seek to explain overtime variation within Latin American countries in the industrial employment share since 1980.

\section{Theories of Industrialization and Deindustrialization}

\section{Productivity and Comparative Advantage}

To industrialize, it has long been clear that LDCs would need to meet basic conditions of urbanization, schooling, and capital investment. ${ }^{5}$ Reflecting 
modernization theory, many scholars optimistically expected that LDCs could certainly industrialize once these basic conditions were met (Kerr, Dunlop, Harbison, \& Myers, 1960; Levy, 1966; Moore, 1965). In his influential theory of industrial employment, Clark (1940/1957) proposed that as an economy develops, the price and relative demand for agricultural products decline, although the demand for industrial products increases. As a result, industrial employment almost mechanically rises.

In recent decades, the prevailing view has basically adopted Clark's (1940/1957) explanation while focusing on the role of worker productivity. This leading model of industrialization and deindustrialization has focused on the abundance and productivity of relatively cheap-skilled workers (Alderson, 1999; Brady \& Denniston, 2006; Dasgupta \& Singh, 2006; Fligstein, 2001; Grant \& Wallace, 1994; Kollmeyer, 2009; Pieper, 2000; Rowthorn \& Wells, 1987). As a country develops economically, agricultural employment is naturally replaced by industrial employment (Bairoch, 1975; Bluestone \& Harrison, 2000). This occurs until a country reaches a point of industrial maturity, after which service jobs replace industrial jobs and service sector growth outpaces that of the industrial sector (Alderson, 1999). After this point of maturity, deindustrialization mainly occurs because fewer workers are needed to produce the same quantity of industrial goods (Bluestone \& Harrison, 2000, pp. 227-229). Therefore, one should be able to explain the stagnation or decline of industrial employment as a result of those basic conditions and the productivity of workers, which initially boosts industrial employment and subsequently leads to less need for high quantities of labor.

Beyond productivity, the prevailing view typically incorporates the comparative advantages of LDCs. Rising productivity does not have a deterministic influence, and LDCs must also maintain a favorable position in the global economy (Guillén, 2001; Wolf, 2004). LDCs should specialize in manufactured goods for which they have a comparative advantage, and LDCs should keep currency cheap so that those manufactured products sell at a lower price internationally. Of course, this idea of specialization and comparative advantage reflects the Heckscher-Ohlin model of trade, which also stipulates that LDCs must be open to trade with other countries (Gilpin, 2001, p. 206). An LDC should be able to increase industrial employment in durable goods if industrial firms can acquire raw materials or parts at lower prices from other countries. Because of such transactions, manufacturers should be able to retain employees and invest in personnel, equipment, and facilities (Bair \& Gereffi, 2001). In turn, industrial employment should grow. In this account, industrialization requires a committed export orientation because exports cushion industries against declines in domestic consumption, boost financial reserves, and contribute to economies of scale that favor sustainable industrial sectors 
(Amsden, 2001; Bairoch, 1975; Londero \& Teitel, 1998). For example, using Heckscher-Ohlin theory, Wood (1994) claims that manufacturing exports trigger industrial employment in LDCs as the abundance of low-skilled labor creates a comparative advantage and lessens the "manufacturing autarky" of developed countries. Dodzin and Vamvakidis (1999) show that increasing trade led to greater industrial employment in what were previously agricultureoriented LDCs. Similarly, Bollen and Appold (1993) demonstrate that manufacturing exports significantly increase industrial employment.

This combination of basic conditions, productivity, and comparative advantage helps explain why the import-substitution industrialization (ISI) era in Latin America was ultimately counterproductive. ${ }^{6}$ More to the point, a stagnating industrial employment share may have occurred because worker productivity stopped improving or had grown beyond some point of maturity, currency became expensive, and countries failed to export manufactured goods. All the while, those key initial basic conditions may have deteriorated if urbanization has plateaued, and schooling and domestic investment declined.

\section{Institutionalism}

Institutions can be thought of as stable agreements and historical settlements that channel, constrain, and regulate the economic behavior of firms and workers and hence explain the economic patterns of industries and nation-states (Fligstein, 2001). Institutions include formal and informal rules, laws, policies, and norms that define the range of legitimate actions of market actors. Thus, an institutional explanation should illustrate influences on industrial employment beyond the standard model of productivity and comparative advantage (Evans, 1995). For our analysis, there are four likely sets of institutions that may affect industrial employment.

First, one striking feature of Latin American political economy is the extensiveness of regional trade agreements (RTAs). For decades, Latin America has had a broad array of legal-political institutions facilitating and regulating international economic exchange (Hirschman, 1968). By 1995, every Latin American country in our sample was a member of at least two RTAs, and the median and mean country was a member of three (Schiff \& Winters, 2003). In Latin America, RTAs regulate the international flow of people, goods, services, and capital. A distinctive feature of this region is that the ascent and diffusion of RTAs grew out of ISI, yet reflects the influence of neoliberalism (Phillips, 2004; Rosen, 2002). Countries aggressively sought to partner with neighbors and within the region as they opened to the global economy, yet also sought to protect favored domestic industries to satisfy domestic elites 
and key constituencies (Phillips, 2004). As a result, RTAs in Latin America are a complex and imperfect patchwork of overlapping and competing institutions. Thus, one can reasonably expect that distinct RTAs may have contradictory effects on Latin American industry (Fligstein, 2005).

Some RTAs may boost industrial employment as they facilitate greater access to consumption markets and encourage investment and trade across borders (Bairoch, 1975). The enactment of the North America Free Trade Agreement (NAFTA), for example, encouraged even greater investment in and contracting with Mexican firms and further opened U.S. markets to Mexican exports (Bair \& Gereffi, 2001; Gereffi, Spener, \& Bair, 2002). Although manufacturing was widespread in export-processing zones near the U.S. border and there had been several prior initiatives to facilitate trade, NAFTA and Chile's free trade agreement with the United States may have triggered even greater industrialization (Rosen, 2002). By contrast, other RTAs might undermine industrial employment because they remove protections for domestic firms, tie countries to the policies of their partners, and enact even greater barriers to those outside the RTA (Bhagwati, 1999, 2008; Collier, 2007). Although RTAs were supposed to be part of a broader opening to the global economy, many RTAs like Mercosur actually established tighter restrictions outside the trade bloc itself (Bhagwati, 2008). Weaker members of RTAs are often forced to acquiesce to the demands and policies of the stronger members. For example, Schiff and Winters (2003) point out that the other members of Mercosur (Argentina, Uruguay, and Paraguay) faced a significant disadvantage in manufacturing as Brazil devalued its currency. Ultimately, the effects of various RTAs on Latin American industrial employment are an empirical question (Fligstein, 2005). Indeed, different RTAs may have different effects.

Second, over the past few decades, many Latin American countries liberalized markets and ushered in programmatic changes toward austerity. This neoliberalism broadly dismantled protections for domestic industry (Barros, 1989). Portes and Hoffman (2003) contend that neoliberalism led to a leaner industrial sector and far fewer of the stable, secure working-class jobs traditionally available in manufacturing. Neoliberalism also undermined public infrastructure and state industrial policy, which weakened manufacturing (Gallagher, Moreno-Brid, \& Porzecanski, 2008; Portes \& Roberts, 2005). One dimension of liberalization involved structural adjustment reforms brought on by the debt crisis. The International Monetary Fund (IMF) signed agreements with many Latin American countries, which forced an implementation of neoliberal policies (Stiglitz, 2002). These IMF agreements eroded the power of labor (Martin \& Brady, 2007) and thus may have curtailed labor's capacity to resist cutbacks in manufacturing jobs and the closing of industrial facilities 
(Armbruster-Sandoval, 2005). If countries accepted IMF funds to alleviate balance of payments and currency crises or to make programmatic change, the IMF had tremendous leverage over the country (Vreeland, 2003). Another dimension of liberalization involved the legal opening of capital markets. As cross-border financial transactions were deregulated, investors were enabled to divest from domestic industrial facilities and foreign investors were enabled to make speculative, shorter term investments. Ultimately, these aspects of neoliberalism may have resulted in losses in industrial employment (Harvey, 2005).

Third, Latin American states have been particularly influenced by the military, and Latin American industrialization reflects this imprint (Cardenas, Ocampo, \& Thorp, 2000; Centeno, 2002). Potentially, large and expensive militaries have had a damaging effect on the industrial sector (Kentor \& Kick, 2008). In his earlier study of Brazil, Evans (1979) stresses how the military often had a counterproductive relationship with foreign investors and spent enormous resources on inefficient and wasteful state-sponsored industrial enterprises. In his more recent study of developmental states, Evans (1995) highlights military regimes as a clear example of predatory states that undermine the industrialization of an LDC. 7 In his classic account of "bureaucratic-authoritarian" military regimes in Latin America, O’Donnell (1973) explains that although these regimes were ideological nationalists for industrialization, they were corrupt and ineffective managers of state-sponsored industries. ${ }^{8}$ Moreover, these military regimes are less democratically responsive. As a result of this different political context, military spending is much less likely to augment industrial employment in Latin America (Centeno, 2002).

Fourth, a central institutional influence on industrialization might be the durability and stability of the governing political regime. On one hand, a central claim in economic sociology has been that firms seek stability in their external environments (Fligstein, 2001). Although firms might prefer a liberalized market and a minimalist state, what manufacturers really need is the predictability of stable institutions. As Hirschman (1968) wrote about Latin America 40 years ago, "An industrialist will consider exporting only when he can be sure either that the basic institutions and policies which vitally affect his foreign operations are highly stable" (p. 28). More recently, Guillén (2001) explains, "The Argentine automobile industry suffered from the zigzags in policymaking and the country's extreme degree of political and economic instability" (p. 178). On the other hand, long-standing regimes might be durable because they have protected themselves against political challengers and dominate the political arena (Evans, 1995). Dominant regimes become ossified, averse to reform, and corrupt with favoritism for certain industries and 
firms regardless of their inefficiencies. Indeed, Evans (1995) stresses that the durability of a state is much less likely to influence industrialization than the character of state-society relationships and the bureaucratic organization of state agencies. Moreover, the most durable regimes might, because of the passage of time, be further along in the process of dismantling ISI and establishing neoliberalism (Barros, 1989; Chibber, 2003; Harvey, 2005; Portes \& Roberts, 2005). Thus, declining industrial employment may result because more politically insulated durable states have more time to dismantle the protections for domestic industry.

\section{Dependency/World-Systems}

Dependency and world-systems (henceforth "dependency") theories have long challenged the optimism of those expecting industrialization in LDCs. Scholars in this tradition advanced the view that there is a relationship of exploitation between LDCs and rich countries (Cardoso \& Faletto, 1979; Evans, 1979; Frank, 1969). For instance, Wallerstein (1974) argued that a Europeancentered world system was established in the long 16th century and continued in subsequent cycles. This system is organized around a core of powerful industrialized countries and a periphery of LDCs (and a small semiperiphery), and a country's location in this system deeply shapes development outcomes. Core countries do most of the manufacturing and use peripheral countries as markets and the source for raw materials (Bairoch, 1975; Bunker, 1985).

Chase-Dunn and Grimes (1995) explain that, in the postcolonial world, the maintenance of the world-system is achieved through "market mechanisms" like trade and foreign investment rather than direct threat and military might. Foreign trade composition, in which peripheral countries export raw materials and resource-based products and import manufactured goods, is an indicator of dependence on the core (Kentor \& Boswell, 2003). Therefore, dependency theorists view open trade as detrimental to the periphery and favor protectionism or disengagement as better for industrialization (Cardoso \& Faletto, 1979). For example, Schwartzman (1995) argues that trade dependence hurt industrialization in Brazil and Mexico, and Schoonmaker (1995) shows that trade dependence, especially with the United States, constrains the Brazilian state's attempts to cultivate domestic industry. Bollen and Appold (1993) find that mineral and agricultural exports as well as manufacturing imports reduce the industrial employment share. More recently, scholars outside dependency theory have argued that dependence on raw material exports can impede industrialization - a phenomenon referred to as the resource curse (Auty, 2000; Collier, 2007). In an argument anticipated by Bunker (1985), 
dependence on raw material exports fails to produce economic linkages into manufacturing, leads to ephemeral and unsustainable boom-bust cycles that actually hinder subsequent industrialization, and distorts development by forcing government subsidization of distant outposts of extraction disconnected from urban populations and economic centers. ${ }^{9}$ To be clear, dependency theorists do not argue that resource-based exports fail to produce any jobs in extraction or related industries. Rather, the claim is that resource-dominated trade undermines overall industrial employment and broader industrialization.

In the 1980s, foreign direct investment (FDI) became a focus of inquiry for dependency scholars. Many claimed that FDI into peripheral countries creates "investment dependence," which impedes development (Bornschier \& Chase-Dunn, 1985; Jorgenson, Dick, \& Mahutga, 2007; London \& Smith, 1988). The argument was that FDI tended to be capital intensive, and therefore failed to trigger employment growth or linkages to other industries and sectors. Despite providing an interesting test of theory, these scholars focused on economic development, not industrialization. ${ }^{10}$ However, it could be reasonable to expect FDI to undermine industrialization in LDCs as well (Frank, 1969). Indeed, Cardoso and Faletto (1979) argued that the initial dependence on foreign capital undermined Latin American industrialization in the long run. Perhaps, one can expect that dependence on foreign capital impedes the development of domestic capabilities for industrialization, thereby preventing a country from industrializing fully (Schrank, 2004, 2008). For example, Evans and Timberlake (1980) found that FDI triggers a rapid and lopsided growth in service employment. They argue that FDI exacerbates urban overcrowding due to the flight from rural areas and that even manufacturing FDI tends to be capital intensive (yielding limited employment). Paus and Gallagher (2008) show that FDI has been ineffective in promoting diversified industrialization in Mexico and Costa Rica (the two biggest recipients of FDI in Latin America). In their comparison of management practices in Japanese-owned consumer electronic maquilodoras and consumer electronic factories of Japan, Kenney, Goe, Contreras, Romero, and Bustos (1998) find limited spillover and learning for the host country.

In sum, dependency theory expects that trade dependence and FDI should have negative effects on the industrial employment share. In particular, manufacturing imports, exports to the United States (as the dominant core country for the region; see Kentor \& Boswell, 2003), agricultural and resource-based exports, and inward FDI should all be negatively associated with industrial employment. Therefore, declining industrial employment could be driven by an increase in these measures of dependency theory. 


\section{Data and Method}

To examine trends in industrial employment in Latin America, we analyze a panel of 20 countries from 1980 to 2006: Argentina, Bolivia, Brazil, Chile, Colombia, Costa Rica, Dominican Republic, Ecuador, El Salvador, Guatemala, Honduras, Jamaica, Mexico, Nicaragua, Panama, Paraguay, Peru, Trinidad and Tobago, Uruguay, and Venezuela. To be included in our sample, a country had to have a population of at least 500,000 and data on industrial employment for several time points. ${ }^{11}$ Data have been collected for years circa 1975, $1980,1985,1990,1995,2000,2003$, and 2006. The unit of analysis is the country-year. Because of occasional missing country-years for the dependent variable, there is an average of 6.7 observations per country and the total number of observations is $134 .{ }^{12}$ Appendix $\mathrm{C}$ presents descriptive statistics and sources for all variables.

\section{Dependent Variable}

The dependent variable is the Industrial Employment Share, which is calculated as industrial employment as a percentage of total employment in a country-year. As mentioned above (see Note 1), this is the standard measure. ${ }^{13}$ The industrial share includes standard industrial classification codes (rev. 3) C-F, and all remaining employment is coded as either service or agriculture. Unfortunately, data are not available prior to 1980 , so this is the basis for beginning the dependent variable then. Moreover, a pooled time series including all years is not possible because of missing data.

\section{Independent Variables}

We organize our analysis around the three theoretical explanations. As some variables exhibit skew and have outliers, we employ a decision rule that whenever a variable had a skew above 2.0 , we convert it to a natural log. To increase confidence in the causal time order, we lag all independent variables one time period. Thus, the first observation for each independent variable in 1975 predicts industrial employment in 1980 (and 2003 independent variables predict industrial employment in 2006).

Primarily, we examine eight measures for the productivity and comparative advantage explanation. ${ }^{14}$ Following previous research (e.g., Alderson, 1999; Brady \& Denniston, 2006; Dasgupta \& Singh, 2006; Kollmeyer, 2009), we measure productivity with Real GDP Per Capita (GDP). As these countries 
became more productive, this could contribute to growth in industrial employment share. To explore if GDP has an inverse U-shaped relationship with industrial employment, we also consider Real GDP Per Capita-Squared. Both GDP and its square are logged. Next, we include Inflation to measure the price structure affecting industrialization including the cost of labor and other production factors as well as the value of the currency. ${ }^{15}$ This variable is also logged. Secondary School Enrollment is measured as net enrollment for age appropriate population and gauges the effect of the skill level of the labor force. Urbanization is the percentage of the population living in urban areas. Gross Fixed Capital Formation as a percentage of GDP is also included. This is measured as the gains in fixed assets plus the net change in the inventory levels and is considered a measure of the domestic investment rate (World Bank, 2010). Finally, Exports measured as a percentage of GDP and Manufacturing Exports calculated as a percentage of all exports are included to assess outward trade orientation. According to the productivity/comparative advantage explanation, these last six variables should have positive effects.

Second, we examine eight variables for the institutional explanation. We include a set of binary variables indicating membership in the most important RTAs. Membership in RTAs may have significant albeit conflicting effects on industrial employment. Membership in the Central American Group of Four includes El Salvador, Guatemala, Honduras, and Nicaragua. Membership in Mercosur measures the RTA among Brazil, Argentine, Paraguay, and Uruguay. Although Venezuela is in the process of becoming a full member, and Bolivia, Chile, Colombia, Ecuador, and Peru are associate members (Schiff \& Winters, 2003), we only include the four full members. Membership in the Association of Caribbean States is an association of 28 states aimed at strengthening regional cooperation. Next, we include a dummy for having a Free Trade Agreement With the United States. In addition to Mexico, a member of NAFTA since 1994, we code Chile in 2006 positively. ${ }^{16}$ Two variables assessing liberalization should have negative effects. Receiving an IMF Credit is a binary measure of not only having a stand-by agreement but also actually receiving financing from the IMF. Rather than the existence of an agreement (Vreeland, 2003), whether the IMF actually lent funds indicates the most leverage for neoliberalism. ${ }^{17}$ Capital Accounts Liberalization is Chinn and Ito's (2008) index of legal openness in capital accounts transactions. This index ranges from -1.8 to 2.54 , with positive values indicating liberalization. Also, we include logged Military Expenditures as a Percentage of GDP ${ }^{18}$ which should have a negative effect. Finally, Duration of the Current Political Regime is measured in years since the existing constitution was implemented. Although some suggest that the durability of a political regime creates a more stable and less risky environment 
for business, others imply that longer lasting regimes might undermine industrial employment.

Third, to assess dependency theory, we consider eight variables. We first analyze the levels and composition of international trade. The first two examine inward trade: Imports as a Percentage of GDP and Manufacturing Imports as Percentage of All Imports, which could potentially undermine industrial employment. Next, we examine outward trade while controlling for Exports as a Percentage of GDP. We examine the composition of exports with Agricultural Exports, Fuel Exports, and Mineral and Ore Exports as a percentage of all exports (food and services exports are the omitted reference). These three measures of export composition are logged. In dependency theory, the periphery exports raw materials, natural resources, and agricultural commodities and imports manufactured products. Accordingly, these should have negative effects on industrial employment (especially net of the level of exports). In addition, we add Exports to the United States as a Percentage of All Exports, which is logged. The United States has historically been the largest trade partner for most Latin American countries. ${ }^{19}$ Trade partner concentration has long been a concern for dependency scholars, and as a result, this variable should have a negative effect. Finally, we add logged Foreign Direct Investment Flows as a Percentage of GDP (FDI) ${ }^{20}$ As there is considerable annual fluctuation in FDI flows, this variable is a 3 -year average $(t-1, t, t+1)$. According to our interpretation of dependency theory, one should expect a negative effect.

\section{Models}

Ordinary least squares (OLS) is not appropriate because panel data violate the assumption of independent errors (Wooldridge, 2003). Because of the potential for unmeasured time-invariant cross-national heterogeneity, we use FE models (Wooldridge, 2003). FE models effectively control for unobserved unit effects, which if ignored trigger bias and inconsistency. FE models are also more effective against reverse endogeneity (Winship \& Morgan, 1999). FE models run OLS after differencing variables from their country-specific means. The FE model can be represented as follows

$$
Y_{i t}=\alpha_{i} C_{i}+\beta X_{i t-k}+\varepsilon_{i t}
$$

which is then estimated by

$$
\left(Y_{i t}-\bar{Y}_{i}\right)=\alpha_{i}\left(C_{i t}-\bar{C}_{i}\right)+\beta\left(X_{i t-k}-\bar{X}_{i}\right)+\left(\varepsilon_{i t}-\bar{\varepsilon}_{i}\right)
$$


The subscript $i$ represents a country and $t$ represents a year $(t-k$ represents lagged values). $Y$ represents industrial employment share, $C$ is a vector of country-dummies (which drop out in the second model), and $X$ represents a vector of independent variables. As the FE model differences each observation from its country-mean $(\bar{X})$, all cross-national differences are removed. However, the reasonable number of observations per country in our sample (6.7 on average) and the moderate number of countries ( 20 countries) makes the use of FE models feasible. Finally, given our theoretical interest in the over-time trends in industrial employment, FE models appropriately concentrate on variation within (over-time) countries. ${ }^{21}$

\section{Results}

We first specify models for the productivity/comparative advantage explanation. Then, retaining the key variables from this prevailing explanation, we examine the institutional and dependency explanations separately. Finally, we combine the key significant variables from each explanation into final models.

\section{Productivity and Comparative Advantage Models}

The first model of Table 1 includes both GDP per capita and its square. This model reveals that rising worker productivity has a significant negative effect on industrial employment at the .05 level. As GDP per capita-squared is insignificant, there is no evidence of a curvilinear inverse U-shaped relationship with industrial employment as has been shown in developed countries (Alderson, 1999; Brady \& Denniston, 2006; Kollmeyer, 2009). Somewhat surprisingly, rising worker productivity linearly reduces the industrial share of employment. ${ }^{22}$ The second model includes only the linear term and confirms that GDP per capita has a significant linear negative effect. Model 2 also fits the data better than Model 1. The next two models consider both specifications as alternatives.

Model 3 includes GDP and its square and the remaining productivity/ comparative advantage variables. Inflation is the only variable with a significant effect $(+)$, although gross fixed capital formation is nearly significant $(t>1.5)$. This suggests some comparative advantages for industry when currency is cheaper. In Model 3, both GDP and its square are insignificant. In addition to the insignificance of secondary school enrollment and urbanization, it is noteworthy that neither total exports nor manufacturing exports has 


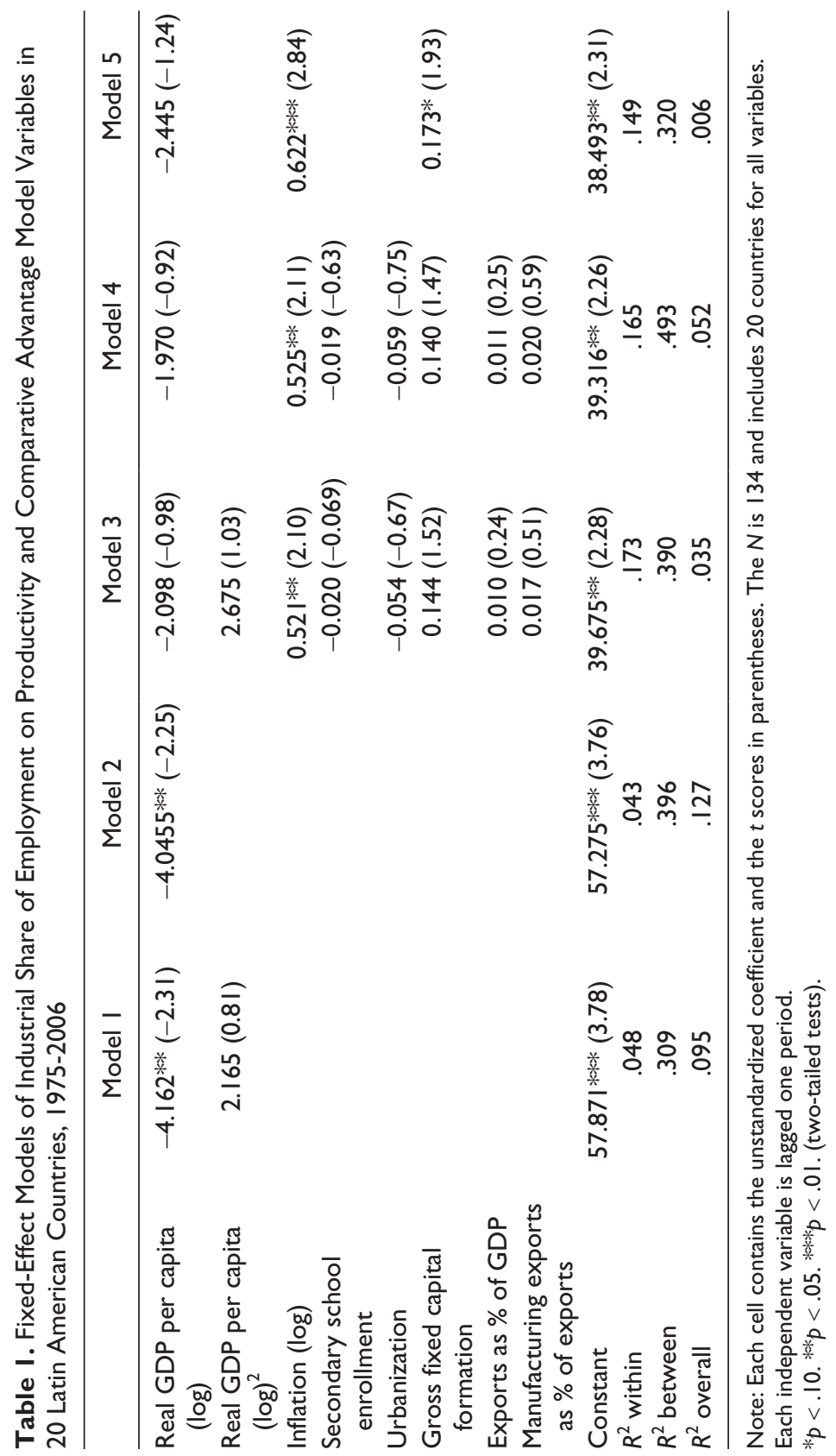


a significant effect. Exports and manufacturing exports have actually grown or been stable in most Latin American countries since 1975. ${ }^{23}$ Thus, the problem is not an absence or decline of exports or manufacturing exports. Unlike the well-documented East Asian successes, exports do not appear to have effectively triggered an expansion of industrial employment in these Latin American countries. These results are robust when GDP-squared is removed in Model 4.

The final models in Table 1 include GDP, inflation, and gross fixed capital formation. Although only inflation has robust significant effects, these three are the most promising indicators of the productivity/comparative advantage account. In Model 5, gross fixed capital formation becomes significant at the .10 level, and GDP is negatively signed but not quite statistically significant. Henceforth, we retain these three. ${ }^{24}$

\section{Institutional Models}

Table 2 presents the models of industrial share of employment on the three productivity variables, plus the variables for the institutional explanation. Model 1 features indicators for the four RTAs. Similar to the previous table, inflation has a significant positive effect. Among the RTAs, membership in the Central American Four has a significant positive effect on industrial employment and a free trade agreement with the United States has a near significant positive effect $(t=1.6)$. By contrast, memberships in Mercosur and the Association of Caribbean States have significant negative effects on industrial employment at the .01 and .05 level, respectively. Interestingly, and as anticipated by the literature (Fligstein, 2005), we find that different RTAs have distinct effects on industrial employment.

The second model demonstrates that the two liberalization variables do not have significant effects, although capital accounts liberalization is negatively signed $(t>-1.4)$. These insignificant results are identical if the two are tested in separate models or if either/both are added to other models. Model 3 shows that military expenditures have a significant negative effect at the .10 level. This illustrates the harmful influence of the military on industrial employment. In Models 2 and 3, inflation $(p<.01)$ and gross fixed capital formation $(p<.10)$ now have significant positive effects. Model 4 demonstrates that the duration of the current political regime has a significant negative effect at the .05 level. This result challenges claims that regime stability enhances industrialization and supports claims that longer tenures for political regimes allow for ossification and the dismantling of ISI. 


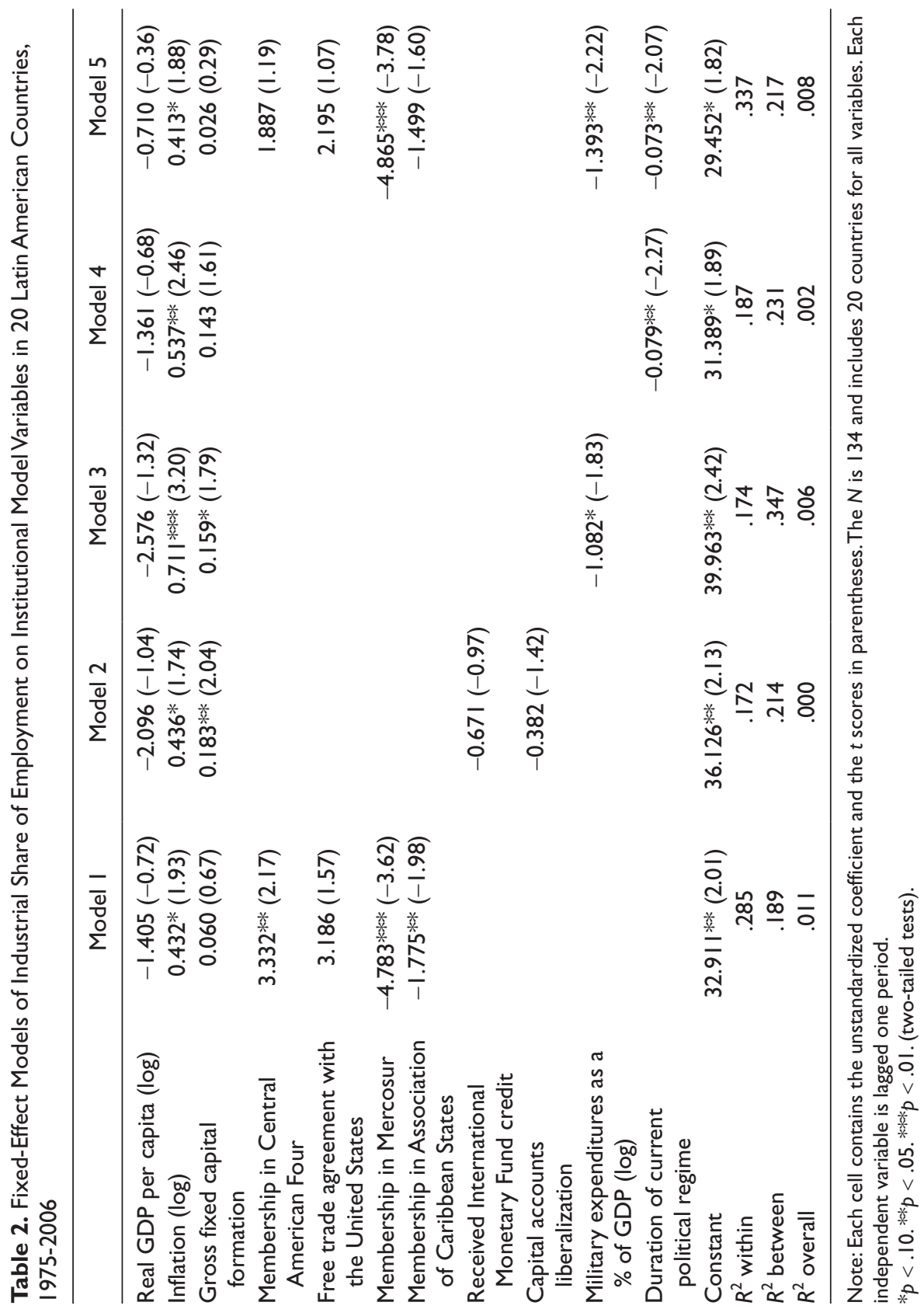


Model 5 includes all variables except the liberalization variables. Inflation has slightly less significant positive effect $(p<.1)$, whereas GDP per capita and gross fixed capital formation are insignificant. Among the RTAs, only membership in Mercosur has a significant negative effect $(p<.01) .{ }^{25}$ Military expenditures and the duration of the current political regime still have significant negative effects. We retain these three significant variables as the key institutional indicators in the final models below.

\section{Dependency/World-Systems Models}

Table 3 presents the models of industrial employment on the productivity/ comparative advantage and dependency variables. Model 1 focuses on the structure of imports. In this model, inflation and gross fixed capital formation have significant positive effects. The extent of imports (as a \% of GDP) does not have a significant effect, whereas manufacturing imports have a significant negative effect $(p<.10)$. This suggests that a high composition of manufacturing imports undermines industrial employment, whereas there is no effect of imports generally. The second model examines the structure of exports. Inflation now has a very significant positive effect. Exports to the United States have a significant positive effect, whereas mineral and ore exports have a very significant negative effect. By contrast, the level of exports (as a \% of GDP) and agricultural and fuel exports do not have significant effects. ${ }^{26}$ The significant negative effect of mineral and ore exports supports dependency theory, which argues that peripheral countries suffer from trade dependency in which they rely on the extraction of natural resources. However, the positive effect that exports to the United States provides is contrary to dependency claims regarding partner concentration. This suggests that exports to the United States actually facilitate industrialization in Latin America.

Model 3 tests the effect of FDI on industrial employment. FDI's effect is significant at the .10 level $(p=.052)$, which supports dependency theory. Also, consistent with dependency, gross fixed capital formation now has a larger and more significant positive effect in this model, plausibly reflecting the distinctly beneficial effects of domestic investment — which become more apparent when controlling for FDI.

Model 4 includes the productivity/comparative advantage variables and the significant dependency variables from Models 1-3. In Model 4, none of the productivity/comparative advantage variables is significant. Among the trade variables, manufacturing imports now becomes insignificant, and 


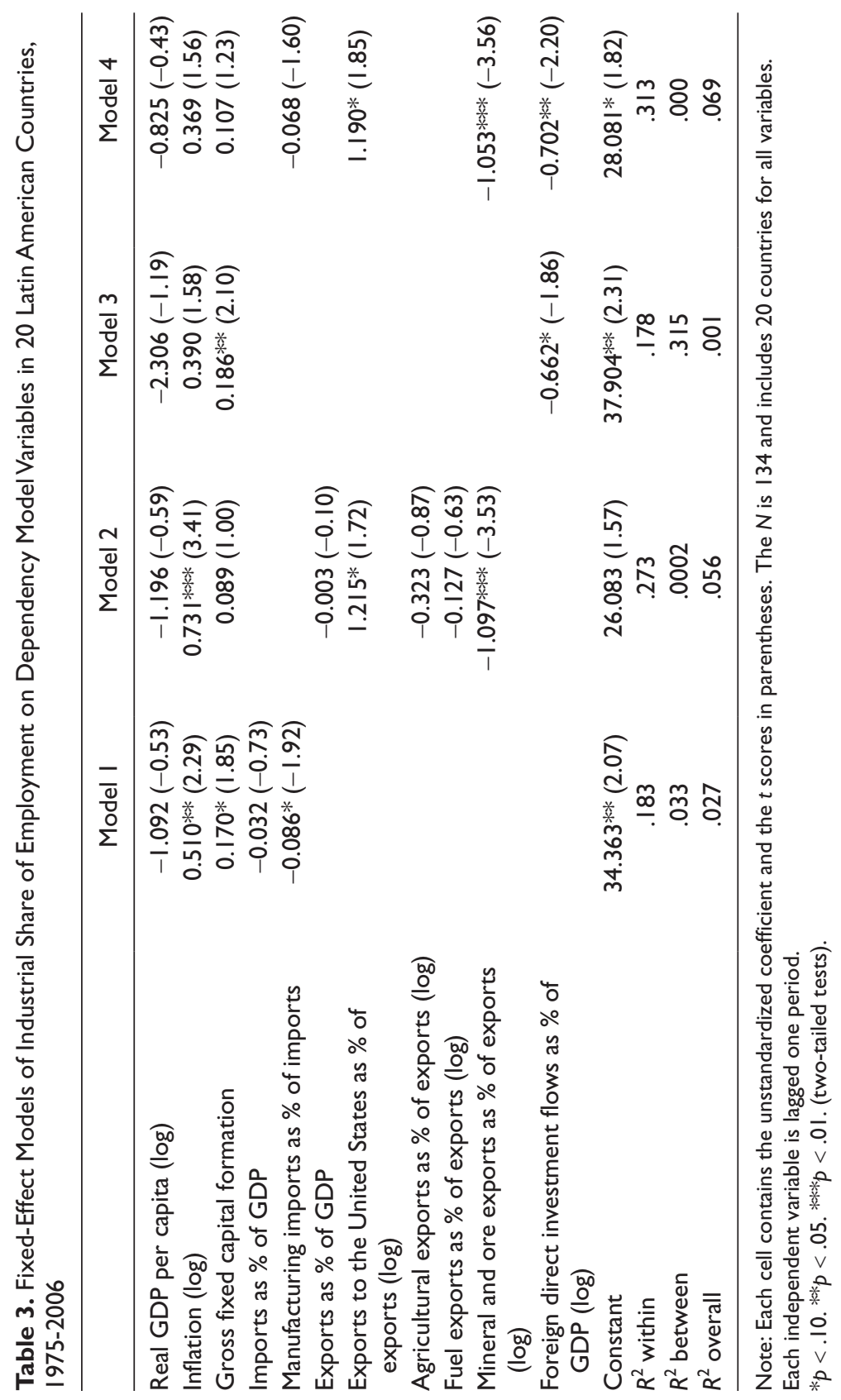


the effects of exports to the United States $(+)$ and mineral and ore exports (-) remain significant. Finally, FDI inflows have a more significant negative effect on industrial employment. In turn, we retain these last three variables for the final models.

\section{Final Models}

Based on substantive and statistical significance, model fit, and robustness under a variety of specifications, Table 4 combines the most important variables from Tables 1-3. Here, we also report standardized coefficients (semistandardized for the Mercosur binary variable). The first model demonstrates that all three of the productivity and comparative advantage variables are insignificant and would have small effects. None of the standardized effects would exceed .12, and all $T$-scores are less than 1.5. We also estimated an $F$ test of the joint significance of these three variables. The $F$ test failed to reject the hypothesis that these variables were collectively equal to zero $(p=.98)$. In turn, there is no support for the productivity/comparative advantage explanation. Although these variables were occasionally significant in earlier models, their effects are ultimately not robust.

In this first model, all three institutional variables are significantly negative. With membership in Mercosur, industrial employment should decline by about .64 standard deviations (holding all other variables constant at their means). With a standard deviation increase in logged military expenditures, industrial employment should decline by .28 standard deviations. For a standard deviation in the length of the current political regime ( $\sim 17$ years), industrial employment is expected to decline by about .33 standard deviations. Thus, each of the institutional variables is statistically and substantively significant. An $F$ test shows that their effects are collectively significantly different from zero $(p=.001)$. Thus, the institutional explanation outperforms the productivity/comparative advantage explanation.

In the first model, two of the three dependency variables are significant. Although positively signed, logged exports to the United States is now insignificant. Even if it was significant, it would have a modest effect $(\beta<.15)$. Thus, this apparent challenge to dependency theory in Table 3 is not robust in the final models. Consistent with dependency theory, both mineral and ore exports and FDI have significant negative effects on industrial employment. With a standard deviation increase in logged mineral and ore exports (as a \% of total exports), industrial employment should decline by .44 standard deviations. With a standard deviation increase in logged FDI flows (as a \% of GDP), 


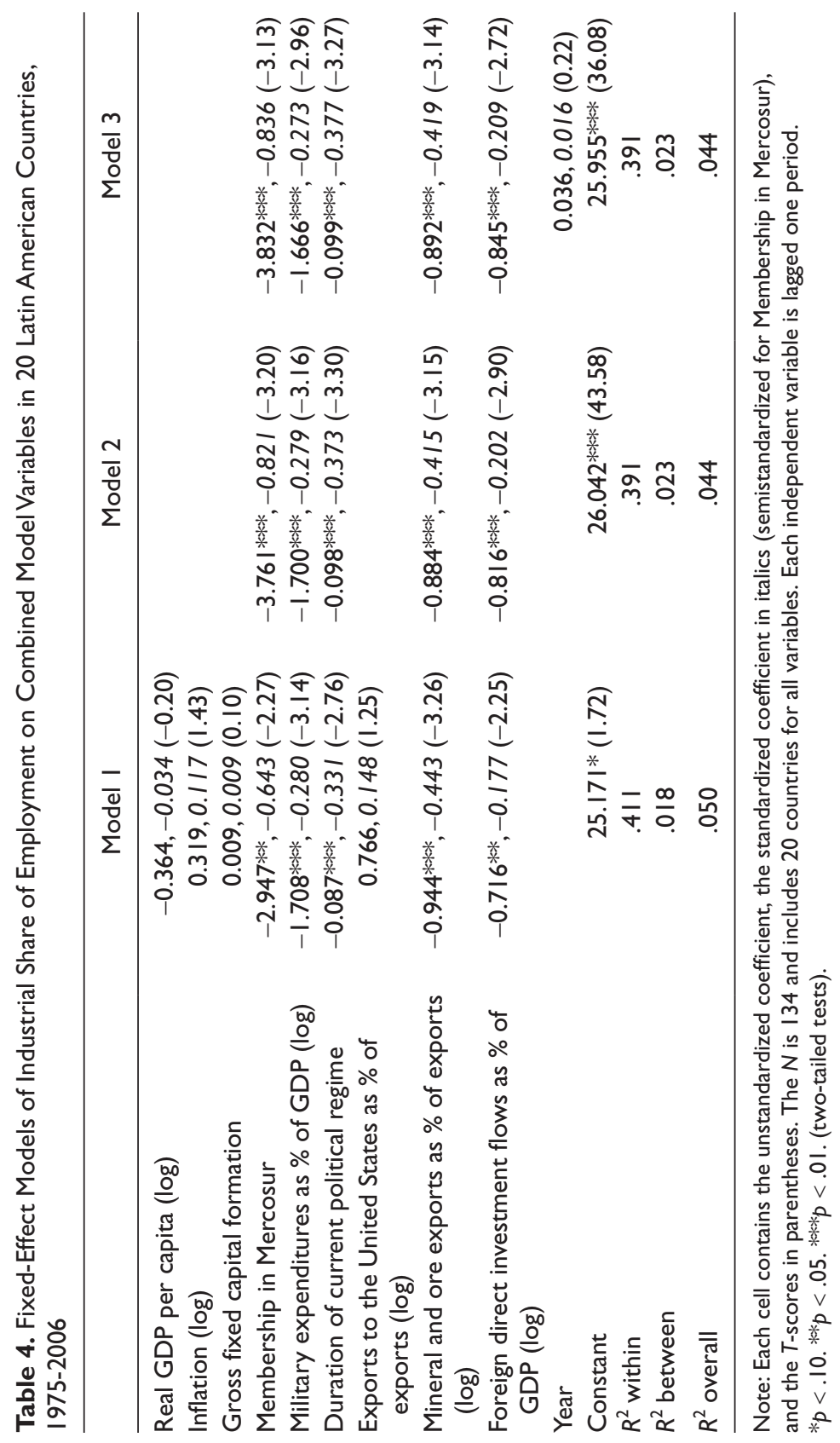


industrial employment should decline by .18 standard deviations. An $F$ test reveals that the two significant dependency effects are collectively significantly different from zero $(p=.0002)$. Like the institutional explanation, the dependency explanation is more useful than the productivity/comparative advantage explanation.

Model 2 removes the productivity/comparative advantage variables as well as the exports to the U.S. variable to provide a more parsimonious final model. In this final model, the size and significance of a few effects fluctuate, but the main conclusions are consistent (indeed the effects of three of the five significant variables are slightly more pronounced). In order of magnitude, membership in Mercosur, mineral and ore exports, the duration of the current political regime, military expenditures, and FDI flows all significantly reduce industrial employment. Therefore, the stagnation of the industrial employment share in Latin America appears to result from a combination of institutional and dependency variables. By contrast, the productivity/comparative explanation does not contribute to explaining the trends.

The third and last model in the table adds a year variable (coded 0-6) to Model 2. The year variable does not have a significant effect on industrial employment and the other results are consistent with Model 2. This suggests that there is no residual trend in industrial employment that cannot be explained by the key institutional and dependency variables. The insignificance of year can be contrasted with the second model in Appendix A, where this year variable was significant. ${ }^{27}$ Moreover, the robustness of the significance of the key variables even with year in the model provides evidence that these variables are not simply proxying time. Hence, this combination of institutional and dependency variables can explain the previously identified downward trend for industrial employment.

In addition to those mentioned in Notes, we conducted two final sensitivity analyses. First, although FE models with lagged independent variables should alleviate the problem (Winship \& Morgan, 1999), some significant effects could occur because the independent variables are endogenous to industrial employment. In analyses available on request, we made each independent variable the dependent variable in an FE model containing lagged industrial employment. Second, we estimated Model 2 of Table 4 while removing one country at a time. Although there were a few exceptions, both of these sensitivity analyses generally confirm the robustness of our results. ${ }^{28}$

Although there is substantial cross-national variation within each year, temporal trends in the central tendencies of these key independent variables can be informative to explaining the trends in the dependent variable. The 


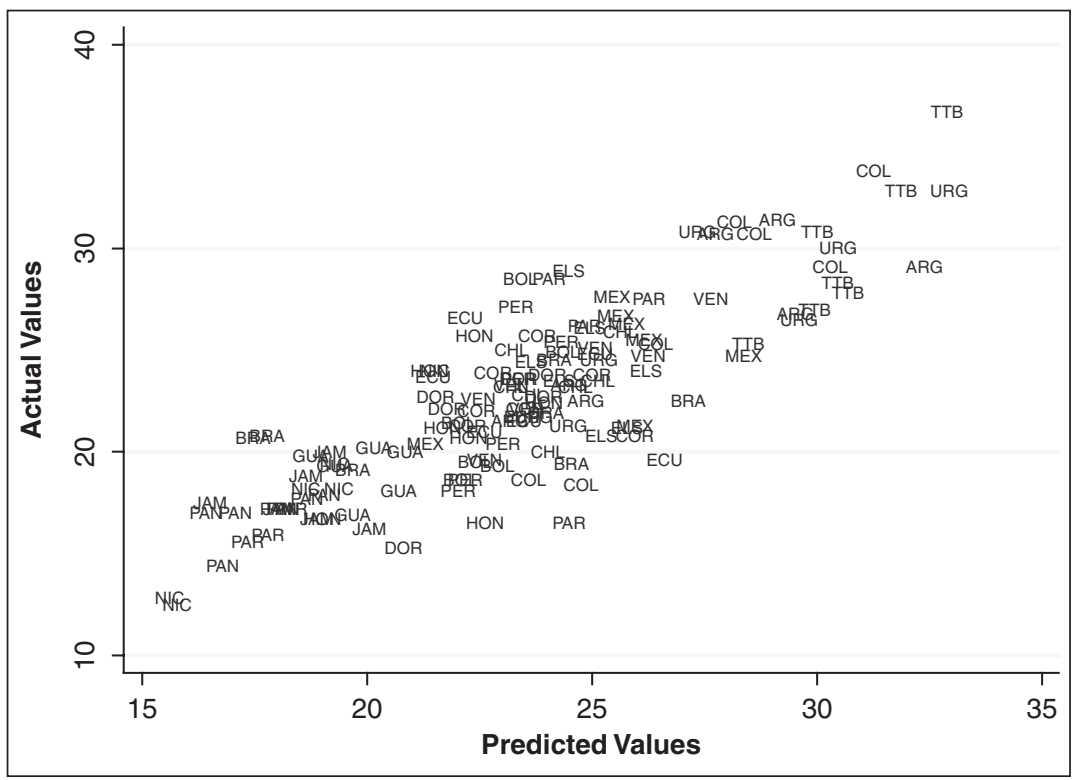

Figure 2. Actual and predicted industrial employment in 20 Latin American countries (1980-2006)

median and mean value of mineral and ore exports, FDI flows, and regime durability were higher in 2000 and 2003 than 1995, so the rise of these three has contributed to declining industrial employment. Mercosur was zero for all cases prior to 1995, and 1 for four countries after, which also contributed to declining industrial employment. By contrast, military expenditures declined since at least 1990 in 16 of the countries, so this has partly alleviated the decline caused by the other factors. ${ }^{29}$

To illustrate how Model 2 explains the actual values, we generated predicted values. The predicted values from Model 2 correlate quite well with the actual values of industrial employment from 1980 to $2006(r=.84, N=134)$. In Figure 2, we plot the predicted and actual values. As Figure 2 reveals, there are no obvious outliers. Perhaps, this model slightly overestimates a few years for Brazil, Ecuador, and Bolivia, and slightly underestimates a few years for the Dominican Republic, Honduras, and Paraguay. Nevertheless, Figure 2 demonstrates that the final model explains actual industrial employment reasonably well. 


\section{Discussion}

The prevailing account in extant studies of industrialization and deindustrialization has been the productivity/comparative advantage explanation (Alderson, 1999; Brady \& Denniston, 2006; Dasgupta \& Singh, 2006; Kollmeyer, 2009; Pieper, 2000). According to this view, industrialization should occur after basic conditions of urbanization, schooling, and investment have been met. Then, rising worker productivity, cheaper currency, and an export orientation should boost industrial employment. Industrial employment should only decline when those factors decline or when much higher productivity has been achieved. Surprisingly, we find little evidence that these factors can explain trends in Latin America. GDP per capita does not exhibit positive effects or an inverse U-shaped relationship, and there is only nonrobust evidence that rising productivity had a linear negative effect. This suggests that these Latin American countries are not experiencing deindustrialization in the same way as was experienced by affluent democracies (see Alderson, 1999; Brady \& Denniston, 2006; Kollmeyer, 2009). There was some evidence that inflation and gross fixed capital formation enhanced industrial employment, but these effects were not robust. Importantly, manufacturing exports (as a \% of exports) and exports (as a \% of GDP) both increased substantially over the period and throughout the region. Even though export-oriented development has clearly benefited East Asian industrialization, it does not appear to have had the same effects in these Latin American countries. In turn, this study suggests some limitations of this prevailing account outside developed countries and East Asia.

Our study reveals several important institutional influences on industrial employment in these Latin American countries. In particular, we provide evidence that the Mercosur RTA, military spending, and regime durability undermined industrial employment. Most likely, Mercosur had negative effects because it removed protections for domestic industries, tied countries to policies of neighbors like Brazil, and set up barriers to trade outside the RTA. Since the onset of Mercosur, Brazil maintained relatively stable or only modestly declining industrial employment. However, the other and smaller partners suffered dramatic declines in industrial employment. Prior to Mercosur in 1990, the industrial employment share was 31.6\% in Argentina and 33\% in Uruguay. By 2003, both had fallen below 22\%. Even though this RTA may have boosted trade among partners, it also enacted barriers to those outside the RTA. The negative effect of regime durability may be surprising to some. After all, institutional stability is considered essential to business expansion 
and investment. Nevertheless, as Evans (1995) implies, we find that regime stability is less consequential than the character of state-society relationships and the bureaucratic organization of state agencies. It is plausible that durable regimes have negative effect because they are often protected against challengers, loyal to established elites, and favoring inefficient firms and industries. At the same time, such politically insulated regimes might also be further along in dismantling ISI and removing protections for domestic industry (Barros, 1989). The most vivid example of this is Colombia, one of the oldest regimes in the region, which fell from 34\% industrial employment share in 1980 to below 19\%. By contrast, Nicaragua actually industrialized from the 1980s to the 1990s despite having a nascent regime. Observers of Latin American history cannot miss the prominent role of the military, and extensive military spending has apparently undermined industrial employment. Perhaps, military spending has a negative effect because large militaries are a counterproductive drain on resources and because they are emblematic of predatory states. This is best exemplified by Colombia's striking decline while military spending rose from an average of $1.5 \%$ of GDP during 1975-1985 to an average of 2.6\% during 1990-1995 and 3.9\% during 2000-2003. The corrosive effect of military spending is also illustrated by Trinidad and Tobago's very small military and relatively extensive industrial employment, and Guatemala's growing industrial employment as military spending declined in the 1990s. One positive development in the past few decades has been the decline of the military in most of Latin America. This has partially offset the other significant factors that have undermined industrial employment.

Traditionally, dependency theory has been focused on economic development in general. Our study demonstrates that a potentially valuable direction is to decompose development into sectors and industries to scrutinize the consequences of the global economy for workers. At least two key dimensions of dependency theory appear to have contributed to the stagnation of industrial employment. As countries increasingly relied on mineral and ore exports in the 1990 s, and began to receive more FDI, industrial employment declined. ${ }^{30}$ For example, in the 1980s, Paraguay received very little FDI, yet FDI grew rapidly in the 1990 s as Paraguay fell from nearly $28 \%$ industrial employment to about $16 \%$ by 2003 . In the late 1990 s, both Colombia and Peru experienced rapidly growing FDI and declining industrial employment. Bolivia and Peru always had high levels of mineral and ore exports and experienced substantial declines in industrial employment after 1990. Although there was some evidence that trade with the United States benefited Latin American 
industrialization, this effect was not robust and there was also evidence of negative effects for manufacturing imports.

Finally, an analysis of the lead industries in Latin American manufacturing sector (see Appendix D) shows that Latin American countries remained mainly as producers of the same resource-based industrial products throughout the period studied. This provides further evidence suggesting that industrial employment in Latin America stagnated in recent decades. This also suggests that the stagnation cannot be attributed to a shift toward the production of high-technology or higher value-added products as was the case in the deindustrialization of affluent democracies.

\section{Conclusion}

In the past few decades, the industrial employment share has stagnated in Latin America. This is noteworthy, especially given the worldwide trend of industrialization across LDCs and the visible successes in East Asia. A few others have called attention to the unexpected deindustrialization of certain LDCs (e.g., Dasgupta \& Singh, 2006; Pieper, 2000) and noted the precariousness of manufacturing in Latin America (e.g., Barros, 1989; Moreira, 2007; Portes \& Roberts, 2005). Our analyses build on this work with a comprehensive analysis of industrial employment in 20 Latin America countries. Our results suggest that this stagnating industrial employment was not simply the common cyclical oscillations in expansion and contraction that many LDCs have experienced. Moreover, the stagnation of industrial employment is not only the result of the dismantling of ISI, as most of these countries experienced their peak in industrial employment in the late 1980s and early 1990s (see Appendix B). By contrast, most identify the end of ISI as earlier (Hirschman, 1968; Gereffi \& Wyman, 1990). Finally, the trends in industrial employment in these 20 Latin American countries do not fit much conventional wisdom. Latin America has a comparative advantage in cheap labor, has experienced rising productivity and improving political stability, is proximate to the world's biggest consumer market, and has natural resources. ${ }^{31}$ Even though Latin America industrialized earlier than other developing regions (Gereffi \& Wyman, 1990), industrial employment has stagnated since 1980.

Our study raises several questions for future research. First, the stagnating of industrial employment appears to have occurred at the same time that China experienced rapid industrialization. Perhaps, the stagnation results from the ascent of China (Gallagher et al., 2008; Moreira, 2007). It is reasonable to conclude that East Asian industrialization has somewhat challenged industrial 
employment in these Latin American countries, if only because new investments in industrial facilities are more likely to go to East Asia. Also, there is evidence that specific firms and industries have become less competitive in Latin America because of East Asia (Gallagher et al., 2008). However, we urge caution with this interpretation. Latin America's stagnating industrial employment was already underway by the early 1990s, prior to China's entry into the World Trade Organization in 2001, and certainly before China's most notable industrialization (which most date since 2000). For example, De La Garza Toledo (2007) argues that the crisis of maquiladora system in Mexico in the early 2000s was not due to the rise of China but rather resulted from structural problems within the system. Also, if such a generalized effect of China existed, it should manifest in a significant effect of time/year. As we show in the final models of Table 4, however, there was no effect of year (or any unobserved temporally increasing global factor like China's rise) ${ }^{32}$ Second, although we examine regime durability and military spending, we cannot truly analyze intrastate factors as encouraged by Evans (1995) and others. Future research should combine our cross-national approach with a deeper interrogation of state institutions (e.g., Evans \& Rauch, 1999). ${ }^{33}$ Finally, unfortunately, we are forced to treat all industrial employment equally. It would be valuable to examine specific industries, from autos to textiles to food processing, while maintaining a cross-national approach. Although the global value chains literature offers rich case studies of specific industries, this approach rarely examines a large sample of countries over several decades. Attempts to integrate the scope of cross-national studies with the rich case-specific detail of industries studies would be productive.

After World War II, many Latin American countries began to diversify beyond the extraction of natural resources. This set them on a path of industrialization shaped by ISI and industries like textiles, food, and automobiles (Gereffi \& Wyman, 1990). Subsequently, most Latin American countries expanded exports and moved away from ISI. Heading into the 1990s, it was thought that many Latin American countries could emulate the economic development of the East Asian success stories. Unfortunately, however, since at least the mid-1990s, these Latin American countries have experienced a stagnating, if not declining, industrial employment share. In addition to burdensome international and domestic institutions, this trend appears to be driven by the dependency influences of FDI and natural resource trade. The recent wave of globalization has featured the industrialization of many developing countries. Just as the success stories in East Asia have dramatically transformed the employment of millions of workers, it is crucial to make sense of why Latin America has fallen behind. 


\section{Appendix A}

The Relationship Between Industrial Share of

Employment and Time in 20 Latin American

Countries, 1980-2006 $(\mathrm{N}=134)$

\begin{tabular}{lccc}
\hline & Bivariate correlation & Fixed-effects model & $\begin{array}{c}\text { Fixed-effects model } \\
\text { (reference }=1995)\end{array}$ \\
\hline Year $(0-6)$ & $-0.214^{* *}$ & $-0.432^{* *}(-2.97)$ & \\
1980 dummy & & & $-1.090(-1.06)$ \\
1985 dummy & & & $0.773(0.67)$ \\
1990 dummy & & $0.755(0.73)$ \\
2000 dummy & & $-1.765^{*}(-1.71)$ \\
2003 dummy & & $-2.730^{* *}(-2.64)$ \\
2006 dummy & $24.226^{* *}(45.26)$ & $-2.130^{* * *}(-2.06)$ \\
Constant & .072 & $23.850^{* *}(32.63)$ \\
Within $R^{2}$ & .260 & .161 \\
Between $R^{2}$ & .046 & .260 \\
Overall $R^{2}$ & & .098 \\
\hline
\end{tabular}

Note: Each cell contains the unstandardized coefficient and the $t$ scores in parentheses.

${ }^{*} p<.10 .{ }^{* *} p<.05$.

\section{Appendix B}

Trends in Industrial Share of Employment in 20 Latin American Countries, 1980-2006

\begin{tabular}{lccc}
\hline & 1980 value & Peak value (year) & 2006 value \\
\hline Argentina & 29.3 & $31.6(1990)$ & 23.5 \\
Bolivia & 19.7 & $28.7(1995)$ & 21.6 \\
Brazil & 24.7 & $24.7(1980)$ & 21.0 \\
Chile & 23.7 & $26.1(1995)$ & 23.0 \\
Colombia & 34.0 & $34.0(1980)$ & 18.8 \\
Costa Rica & 24.0 & $25.9(1990)$ & 21.5 \\
Dominican Republic & 15.5 & $23.8(2000)$ & 22.3 \\
Ecuador & 19.8 & $26.8(1990)$ & 21.2 \\
El Salvador & 21.0 & $29.1(1990)$ & 23.7 \\
Guatemala & 17.1 & $20.4(2000)$ & 20.2 \\
Honduras & 16.9 & $25.9(1985)$ & 20.9 \\
Jamaica & 16.4 & $20.2(1995)$ & 17.7 \\
Mexico & 20.6 & $27.8(1990)$ & 25.7 \\
Nicaragua & 13.0 & $24.2(1995)$ & 18.4 \\
\hline
\end{tabular}




\section{Appendix B (continued)}

\begin{tabular}{lccc}
\hline & 1980 value & Peak value (year) & 2006 value \\
\hline Panama & 17.9 & $18.1(1995)$ & 17.2 \\
Paraguay & 26.4 & $28.7(1985)$ & 16.1 \\
Peru & 18.3 & $27.3(1990)$ & 23.8 \\
Trinidad and Tobago & 36.9 & $36.9(1980)$ & 31.0 \\
Uruguay & 30.2 & $33.0(1990)$ & 21.9 \\
Venezuela & 27.7 & $27.7(1980)$ & 22.8 \\
\hline
\end{tabular}

\section{Appendix C}

Descriptive Statistics and Sources for Variables $(N=134)$

\begin{tabular}{|c|c|c|c|}
\hline & M & $S D$ & Sources \\
\hline Industrial share of employment & 22.892 & 4.582 & $\begin{array}{l}\text { World Bank (20I0); } \\
\text { Economic Commission } \\
\text { of Latin America } \\
\text { (Various Years) }\end{array}$ \\
\hline Real GDP per capita (log) & 8.499 & 0.431 & World Bank (20I0) \\
\hline Real GDP per capita $(\log )^{2}$ & 0.185 & 0.214 & World Bank (20I0) \\
\hline Inflation (log) & 2.931 & 1.678 & World Bank (20I0) \\
\hline Secondary school enrollment & 55.105 & 21.741 & World Bank (20I0) \\
\hline Urbanization & 63.052 & 15.517 & World Bank (20I0) \\
\hline Gross fixed capital formation & 19.413 & 4.357 & World Bank (20I0) \\
\hline Exports as \% of GDP & 29.280 & 17.545 & World Bank (20I0) \\
\hline $\begin{array}{l}\text { Manufacturing exports as \% of } \\
\text { exports }\end{array}$ & 26.122 & 19.362 & World Bank (20I0) \\
\hline $\begin{array}{l}\text { Membership in Central } \\
\text { American Four }\end{array}$ & 0.090 & 0.287 & $\begin{array}{l}\text { Schiff and Winters } \\
\text { (2003) }\end{array}$ \\
\hline $\begin{array}{l}\text { Free trade agreement with the } \\
\text { United States }\end{array}$ & 0.030 & 0.171 & $\begin{array}{l}\text { Schiff and Winters } \\
(2003)\end{array}$ \\
\hline Membership in Mercosur & 0.090 & 0.287 & $\begin{array}{l}\text { Schiff and Winters } \\
(2003)\end{array}$ \\
\hline $\begin{array}{l}\text { Membership in Association of } \\
\text { Caribbean States }\end{array}$ & 0.269 & 0.445 & $\begin{array}{l}\text { Schiff and Winters } \\
(2003)\end{array}$ \\
\hline Received IMF credit & 0.269 & 0.449 & IMF (Various Years-a) \\
\hline Capital accounts liberalization & 0.172 & 1.580 & Chinn and Ito (2008) \\
\hline $\begin{array}{l}\text { Military expenditures as \% of } \\
\text { GDP (log) }\end{array}$ & 0.329 & 0.751 & SIPRI (Various Years) \\
\hline $\begin{array}{l}\text { Duration of current political } \\
\text { regime }\end{array}$ & 16.149 & 17.388 & $\begin{array}{l}\text { Marshall, Jaggers, } \\
\text { andGurr (2005) }\end{array}$ \\
\hline
\end{tabular}




\section{Appendix C (continued)}

\begin{tabular}{|c|c|c|c|}
\hline & $M$ & $S D$ & Sources \\
\hline Imports as $\%$ of GDP & 31.186 & 17.316 & World Bank (20I0) \\
\hline $\begin{array}{l}\text { Manufacturing imports as \% of } \\
\text { imports }\end{array}$ & 68.857 & 10.638 & World Bank (2010) \\
\hline $\begin{array}{l}\text { Exports to the United States as } \\
\% \text { of exports (log) }\end{array}$ & 3.400 & 0.884 & IMF (Various Years-b) \\
\hline $\begin{array}{l}\text { Agricultural exports as \% of } \\
\text { exports (log) }\end{array}$ & 0.756 & 1.809 & World Bank (2010) \\
\hline $\begin{array}{l}\text { Fuel exports as \% of exports } \\
\text { (log) }\end{array}$ & 1.025 & 2.601 & World Bank (2010) \\
\hline $\begin{array}{l}\text { Mineral and ore exports as \% of } \\
\text { exports (log) }\end{array}$ & 0.506 & 2.151 & World Bank (2010) \\
\hline $\begin{array}{l}\text { Foreign direct investment flows } \\
\text { as \% of GDP (log) }\end{array}$ & 0.268 & 1.132 & UNCTAD (2008) \\
\hline
\end{tabular}

Note: IMF = International Monetary Fund; SIPRI = Stockholm International Peace Research Institute; UNCTAD = United Nations Commission on Trade and Development. Each independent variable is lagged one period.

\section{Appendix D}

Decomposition of Trends Within Industrial Employment in 20 Latin American Countries, 1980-2006

\begin{tabular}{|c|c|c|c|c|}
\hline & $\begin{array}{l}\text { First lead } \\
\text { industry }\end{array}$ & $\begin{array}{l}\text { First \% of } \\
\text { total industry } \\
\text { employment }\end{array}$ & Last lead industry & $\begin{array}{l}\text { Last \% of } \\
\text { total industry } \\
\text { employment }\end{array}$ \\
\hline $\begin{array}{l}\text { Argentina } \\
\quad(1980-2006)\end{array}$ & $\begin{array}{l}\text { 384, transport } \\
\text { equipment }\end{array}$ & 27.37 & $\begin{array}{l}\text { I5, food products } \\
\text { and beverages }\end{array}$ & 18.03 \\
\hline $\begin{array}{l}\text { Bolivia (1980- } \\
\quad \text { 1988) }\end{array}$ & $3|1-3| 2$, food & 17.64 & $3|1-3| 2$, food & 23.89 \\
\hline $\begin{array}{l}\text { Brazil (1985- } \\
\text { 2006) }\end{array}$ & 3||$-3 \mid 2$, food & 13.46 & $\begin{array}{l}\text { I5, food products } \\
\text { and beverages }\end{array}$ & 16.01 \\
\hline $\begin{array}{l}\text { Chile (1986- } \\
\text { 1990) }\end{array}$ & $3|1-3| 2$, food & 24.47 & $3|1-3| 2$, food & 25.26 \\
\hline $\begin{array}{l}\text { Colombia } \\
\text { (1980-2005) }\end{array}$ & 3||$-3 \mid 2$, food & 14.45 & $\begin{array}{l}\text { I5, food products } \\
\text { and beverages }\end{array}$ & 21.76 \\
\hline $\begin{array}{l}\text { Dominican } \\
\text { Republic } \\
(1981-2006)\end{array}$ & 3||$-3 \mid 2$, food & 72.61 & $\begin{array}{l}\text { 18, wearing apparel; } \\
\text { dressing and } \\
\text { dyeing of furs }\end{array}$ & 22.8 \\
\hline
\end{tabular}

(continued) 


\section{Appendix D (continued)}

\begin{tabular}{|c|c|c|c|c|}
\hline & $\begin{array}{l}\text { First lead } \\
\text { industry }\end{array}$ & $\begin{array}{l}\text { First \% of } \\
\text { total industry } \\
\text { employment }\end{array}$ & Last lead industry & $\begin{array}{l}\text { Last \% of } \\
\text { total industry } \\
\text { employment }\end{array}$ \\
\hline $\begin{array}{l}\text { Ecuador } \\
\qquad(1980-2006)\end{array}$ & 3||$-3 \mid 2$, food & 26.76 & $\begin{array}{l}\text { I5, food products } \\
\text { and beverages }\end{array}$ & 31.86 \\
\hline $\begin{array}{l}\text { El Salvador } \\
(1980-2006)\end{array}$ & $\begin{array}{l}\text { 32, textile, } \\
\text { wearing } \\
\text { apparel, and } \\
\text { leather }\end{array}$ & 32.72 & 37, recycling & 41.88 \\
\hline $\begin{array}{l}\text { Guatemala } \\
(1980-1988)\end{array}$ & 3||$-3 \mid 2$, food & 33.37 & $3|1-3| 2$, food & 30.07 \\
\hline $\begin{array}{l}\text { Honduras } \\
\text { (1985-1998) }\end{array}$ & 3||$-3 \mid 2$, food & 31.74 & $\begin{array}{l}\text { 353-354, petroleum } \\
\text { refineries, } \\
\text { miscellaneous } \\
\text { products of } \\
\text { petroleum and } \\
\text { coal }\end{array}$ & 14.05 \\
\hline Jamaica & NA & & NA & \\
\hline $\begin{array}{l}\text { Mexico } \\
\quad(1980-2006)\end{array}$ & 3||$-3 \mid 2$, food & 12.60 & $\begin{array}{l}\text { I5, food products } \\
\text { and beverages }\end{array}$ & 19.54 \\
\hline $\begin{array}{l}\text { Nicaragua } \\
(1980)\end{array}$ & $3|1-3| 2$, food & 32.61 & NA & \\
\hline $\begin{array}{l}\text { Panama } \\
\qquad(198 I-200 I)\end{array}$ & 3||$-3 \mid 2$, food & 30.79 & $\begin{array}{l}\text { I5, food products } \\
\text { and beverages }\end{array}$ & 51.16 \\
\hline Paraguay & NA & & NA & \\
\hline $\begin{array}{l}\text { Peru (1996- } \\
\text { 2006) }\end{array}$ & $\begin{array}{l}15, \text { food } \\
\text { products and } \\
\text { beverages }\end{array}$ & 29.24 & $\begin{array}{l}15, \text { food products } \\
\text { and beverages }\end{array}$ & 22.32 \\
\hline $\begin{array}{l}\text { Trinidad and } \\
\text { Tobago } \\
\text { (1980-1984) }\end{array}$ & $\begin{array}{l}3 \mathrm{I} \text {, food, } \\
\text { beverages, } \\
\text { and tobacco }\end{array}$ & 25.35 & $\begin{array}{l}31, \text { food, beverages, } \\
\text { and tobacco }\end{array}$ & 26.49 \\
\hline $\begin{array}{l}\text { Uruguay } \\
\qquad(1982-1987)\end{array}$ & $3|1-3| 2$, food & 29.08 & 3||$-3 \mid 2$, food & 26.87 \\
\hline $\begin{array}{l}\text { Venezuela } \\
\text { (1980-1990) }\end{array}$ & $3|1-3| 2$, food & I5.II & 3||$-3 \mid 2$, food & 17.68 \\
\hline
\end{tabular}

Source: Data from the International Labour Organization LABORSTA (http://laborsta.ilo.org/). Note: For Argentina, Brazil, Colombia, Dominican Republic, Ecuador, El Salvador, and Mexico, 1980 is in ISIC Rev 2-3, and 2006 is in ISIC Rev 3-D. For Bolivia, Chile, Guatemala, Trinidad and Tobago, Uruguay, and Venezuela, both time points are in ISIC Rev 2-3. For Nicaragua, 1980 is in ISIC Rev 2-3. For Peru, both time points are in ISIC Rev 3-D.When the industrial classification changes over time, the data may not be comparable over time. As countries provide data at various levels of precision within industrial categories, the data may not be comparable across countries. 


\section{Acknowledgments}

The authors thank Dan Cornfield, Nate Martin, Andrew Jorgenson, Layna Mosley, Karen Remmer, Erik Wibbels, Judith Kelley, Bill Keech, Andrew Schrank, Karina Fernandez-Stark, Yuber Romero, and audiences at Duke's Global Governance and Democracy Workshop and the 2009 SASE meetings in Paris for suggestions.

\section{Declaration of Conflicting Interests}

The authors declared no potential conflicts of interest with respect to the authorship and/or publication of this article.

\section{Funding}

The authors received no financial support for the research and/or authorship of this article.

\section{Notes}

1. Industrial employment share refers to paid employment for a private or public employer as a percentage of total employment. It "corresponds to divisions 2-5 (ISIC revision 2) or tabulation categories C-F (ISIC revision 3) and includes mining and quarrying (including oil production), manufacturing, construction, and public utilities (electricity, gas, and water)" (World Bank, 2010). This is the standard measure and has been consistently used in similar studies of industrialization and deindustrialization (e.g., Alderson, 1999; Barros, 1989; Bluestone \& Harrison, 2000; Brady \& Denniston, 2006; Dasgupta \& Singh, 2006; Dodzin \& Vamvakidis, 1999; Frieden, 2006; Grant \& Wallace, 1994; Kaya, 2010; Kollmeyer, 2009; Rowthorn \& Wells, 1987; Wood, 1994). As we discuss in the Method section below, unfortunately, it is not possible to decompose this general measure of industry into finer grained industries - at least in our sample consistently over time and across countries.

2. It would also be reasonable to interpret this trend as consistent with convergence. In 1980, the coefficient of variation across the 20 countries was .29 . In 1990, it was .23, and in 2006, it was .15. Although this convergence across countries is consistent with decline, it is not our research question.

3. The countries with the smallest within-country ranges were Guatemala (3.3, peak in 2000), Panama (3.5, peak in 1995), and Jamaica (3.8, peak in 1995). All others had a within-country range in excess of 4.5 and 12 exceeded 7.

4. Abramo and colleagues (1997), Abramo (1998), and Cavalcanti (2002) provide excellent reviews of recent studies in the sociology of work in Latin America. They show that, like our study, Latin American social scientists focus on issues of institutional change, state policies, neoliberalism, globalization, and worker power. 
5. Hirschman (1968) argues that industrialization is more likely "to spill from one industry to another" (p. 23) when there are several urban centers in a country (also Bairoch, 1975). Urbanization also proxies how much a country has moved away from agriculture. Wood (1994) stresses that developing countries need at least basic levels of education in their labor forces to use their comparative advantage. Robinson and Briggs (1991) emphasize the role of investment as substantially more important than even rising worker productivity.

6. The import-substitution industrialization (ISI) phase, which occurred after World War II until roughly the late 1970s, was when Latin American countries set up barriers to manufacturing imports to shelter domestic industry. By closing off to foreign trade and investment, this phase ultimately was counterproductive as domestic industries were inefficient, biased against exports, had little access to technology, and reflected patronage more than efficiency. Nevertheless, the protected domestic industries of this era contributed to greater industrial employment (Gereffi \& Wyman, 1990).

7. Evans (1995) treats Brazil as an "intermediate" developmental state that was a "rough approximation of the Weberian ideal" of bureaucracy and one that was able to industrialize partly because of "pockets of efficiency" in the state regime. Like Evans, we find that Brazil was actually moderately successful in maintaining its industrial employment share-declining from $24.7 \%$ in 1980 to $21 \%$ in 2006 (with a low of $19.3 \%$ in 2000 ).

8. Interestingly, these generally negative portrayals of military effects on industrialization seem to be at odds with the beneficial effects of military spending in the United States (e.g., Hooks \& Bloomquist, 1992). Unlike military spending in the United States that contributed to manufacturing growth, Latin American militaries were more likely to import equipment and provided little employment for domestic workers.

9. Schurman (2001) partially challenges the view that resource-based trade undermines industrialization and argues that Chile benefited from an agricultural and natural resource export boom that led to upgrading via the industrial processing of these commodities. However, Schurman also emphasizes that Chile entered a third phase in the 1990s that was much less favorable to industrial employment. Consistent with Schurman, we identify 1995 as Chile's peak for industrial employment and provide evidence of a subsequent decline.

10. We also emphasize this distinction to note Firebaugh's (1992) critique of the denominator effects problem when predicting economic development. So long as industrial employment is not the denominator of the independent variable, our analysis does not suffer from this problem.

11. Unfortunately, because of data unavailability, Cuba and Haiti are not included. The population cutoff excludes small Caribbean countries like Guyana and 
Dominica. Even though we include Caribbean countries in "Latin America," the conclusions are robust if they are omitted.

12. The six missing cases for the dependent variable are in 1985: Bolivia, Dominican Republic, Guatemala, Jamaica, Nicaragua, and Peru. Also, data are not available on an annual basis.

13. One reason studies consistently examine industrial employment share as opposed to the raw number of industrial employees is that data are available on share, but reliable estimates of total employment (the denominator in the share) are often unavailable. Although industrial share of employment is the standard measure, Amsden (2003) argues that manufacturing value added (as a \% of GDP) is a better measure of industrial convergence globally. Manufacturing value added is positively correlated with industrial share of employment $(r=.31, N=125)$. Moreover, year is negatively correlated with manufacturing value added $(r=-.27, N=129)$ and has a significant negative effect in a fixed effects (FE) model $(t=-5.4)$; and this is supported by an FE model with dummies for years (see Appendix A). Therefore, the trend in manufacturing value added is quite similar in Latin America. Please also see Note 30.

14. In analyses available on request, we considered Midford's (1993) measure of comparative advantage in labor abundance, calculated as ([population / world population] / [real GDP / real world GDP]) - 1. This measure is collinear with real GDP per capita $(r=-.92)$. If we include labor abundance in Model 2 of Table 1, real GDP per capita would be significant and labor abundance would not. If we substitute labor abundance for real GDP per capita throughout, our conclusions are consistent (initial positive effect, but not robust in final models).

15. Given our interest in currency, exchange rates are a reasonable alternative. However, exchange rates are heavily shaped by politics, more difficult to measure reliably, and endogenous to exports and financial flows. As rising prices undermine the ability of industrial firms to hire and retain workers, one can also imagine how inflation could have negative effects on the industrial share of employment. Nevertheless, in analyses available on request, we substituted the natural log of exchange rates (currency to dollar) for inflation. This variable was not significant and none of the other results would change.

16. In analyses available on request, we decomposed this variable to assess the precise effect of North America Free Trade Agreement (NAFTA). The results and conclusions were robust.

17. In analyses available on request, we also tested whether a country was under an International Monetary Fund (IMF) agreement, had recently signed an IMF agreement, the cumulative years under IMF agreements (Vreeland, 2003) as well as debt service as a percentage of exports or gross national income. None of these 
alternatives had significant effects, and all were less significant than the IMF Credit variable we report.

18. One alternative would be whether a country experienced a war (Collier, 2007). In analyses available on request, we found that a binary variable for war was not significant (with or without military expenditures in the model).

19. The exceptions are the smaller and landlocked Latin American countries like Paraguay, which rely more on trade with large regional neighbors. As well, several countries have extensive intraregional trade as well as commerce with the European Union. An alternative would be to identify the largest trade partner within each country-year. However, this would neglect the potentially longer lasting and more durable consequences of trade with the largest economy in the hemisphere/world.

20. Unfortunately, foreign direct investment (FDI) stock data are not available for the comprehensive scope of our sample's country-years. Similarly, sector-specific FDI data are only available for 69 of 134 cases (from the United Nations). In analyses available on request, primary (agriculture and mining) and secondary (industrial) FDI flows (as \% of FDI flows) do not have significant effects. These variables remain insignificant controlling for or omitting FDI flows and in separate or combined models. As data are missing for half of the sample, we do not present these results.

21. Partly because we intend our models to explain (rather than correct for) temporal changes, we do not correct for autocorrelation. With 6.7 average time points, the estimation of rho is not likely to be stable. Moreover, FE-AR1 models sacrifice the first time point in each panel, which results in a substantial loss of precious degrees of freedom. To be certain our models did not suffer from serious autocorrelation, however, we estimated the final models with an AR1 correction. The estimates of rho would be .2 or less across Table $4(N=114)$. These low rhos demonstrate that autocorrelation is not a significant problem.

22. Perhaps, these Latin American countries had already reached peak industrial maturity before 1980. However, if so, this would be quite unexpected for developing countries. Austria, Finland, Germany, Ireland, Italy, and Switzerland did not reach peak industrial maturity until the mid-1970s (Brady \& Denniston, 2006).

23. The means and medians of both variables were stable or increasing since 1975, and the coefficients of variation for both variables have been stable or declined. Indeed, the mean/median manufacturing exports (as a \% of exports) almost doubled from $17 \%-19 \%$ (1975-1985) to 32\%-34\% (1995-2006). In analyses available on request, exports and manufacturing exports remained insignificant when added individually or with any combination of the other variables in Model 3.

24. In analyses available on request, we experimented with removing GDP per capita throughout and with including its square throughout. We also retained all 
indicators from this explanation throughout. The results and conclusions were robust.

25. Although membership in the Association of Caribbean States is nearly significant $(t=-1.6)$ in Model 5, it would not be significant if retained in the final models. For example, if included in Model 1 or 2 of Table 4, the $T$ score for this variable would not exceed -.2. Therefore, we do not retain it despite this near significance.

26. The results are robust if we omit the overall level of exports (or any of the export composition measures).

27. The year variable is not lagged. In analyses available on request, we added dummies for time periods like the third model in Appendix A. In this model, the results are mostly consistent and none of the period dummies is statistically significant.

28. As an independent variable, industrial employment only had a significant effect on Mercosur. In the 1st year of Mercosur (1995), the four member countries had a slightly lower mean industrial employment (22.5) than the 16 nonmember countries (24.1). However, a $t$ test shows this difference was not significant, and therefore Mercosur countries do not appear to be selectively less industrialized. When each country was omitted, the five variables were all robustly significant in 99 of 100 models (the exception was mineral and ore exports when Paraguay was excluded, yet the coefficient still remained negatively signed).

29. The clear exception is Colombia, where military spending grew significantly, and, to a lesser extent, Brazil, Ecuador, and Panama, where it was stable.

30. Latin America has experienced a primary products boom in the past 5 to 10 years, and this could have mechanically shifted a greater share of employment into mineral and ore sectors as those sectors grow (without a clear decline in the number of industrial jobs). Perhaps, this is simply "statistical deindustrialization" as industrial employment is stable (or declining modestly) and other sectors are growing rapidly. We do not believe this is the case, however. It is not clear that there has been a rise in mineral/ore extraction jobs (as those industries are quite capital intensive) and those exports could have driven a growth in related and tightly coupled mineral/ore extraction industry. Moreover, manufacturing exports as a percentage of total exports have grown substantially from 17\%-19\% (19751985 ) to $32 \%-34 \%$ (1995-2006). Therefore, rising mineral and ore exports have not come at the expense of manufacturing exports, and, certainly, one could have expected those rising manufacturing exports to generate more industrial jobs.

31. Given Latin America's proximity to the United States, readers may ask why we have not analyzed immigration. In analyses available on request, however, we found that several measures of net migration (as a \% of population) and migrant remittances (logged as a \% of GDP) did not have significant effects. These insignificant effects probably owe to theoretically plausible countervailing impacts of migration. Although migrants can invest or send capital back, which might foster 
industrial employment, the flight of young workers erodes the consumption base and the pool of laborers and entrepreneurs.

32. Moreover, it is important to keep in mind that worldwide industrial employment is not a zero-sum game. There is no reason that industrial employment cannot grow in both East Asia and Latin America. After all, industrial employment grew in many (not just one or a few) East Asian countries, and in South Asia, the Middle East/North Africa, and to a limited extent in Sub-Saharan Africa. Therefore, we should not assume that East Asia "competes" with Latin America for a limited global quantity of industrial jobs. The question is why Latin America's industrial employment share stagnated while almost every other region of less developed countries industrialized.

33. It might be reasonable to consider democracy or government expenditures (or their interaction) as measures of state efficacy (i.e., Evans" "Weberianness"). However, these variables suffer from reverse causality, as there is an extensive literature claiming that democracy and state size are endogenous to industrialization. In analyses available on request, we found that if either democracy or government consumption (as \% of GDP) was added to the final model, neither would be significant $(t<|.9|)$.

\section{References}

Abramo, L. J. C. V., De La Garza Toledo, E., De Paula Leite, M., Novick, M., Satiago, C. A., \& Da Silva, R. (1997). The Institutionalization of the Sociology of Work in Latin America. Work and Occupations, 24, 248-363.

Abramo, L. (1998). The sociology of work in Latin America: A complex development and current challenges. Work and Occupations, 25, 305-332.

Alderson, A. S. (1999). Explaining deindustrialization: Globalization, failure, or success? American Sociological Review, 64, 701-721.

Amsden, A. H. (2001). The rise of the rest. Oxford, UK: Oxford University Press.

Amsden, A. H. (2003). Good-bye dependency theory, hello dependency theory. Studies in Comparative International Development, 38, 32-38.

Armbruster-Sandoval, R. (2005). Workers of the world unite? The contemporary anti-sweatshop movement and the struggle for social justice in the Americas. Work and Occupations, 32, 464-485.

Auty, R. M. (2000). How natural resources affect economic development. Development Policy Review, 18, 347-364.

Bair, J., \& Gereffi, G. (2001). Local clusters in global chains: The causes and consequences of export dynamism in Torreon's blue jeans industry. World Development, 29, 1885-1903.

Bairoch, P. (1975). The economic development of the third world since 1900. Berkeley: University of California Press. 
Barros, J. G. (1989). Deindustrialization in Chile. Boulder, CO: Westview.

Bhagwati, J. (1999). Regionalism and multilateralism: An overview. In J. Bhagwati, P. Krishna, \& A. Panagariya (Eds.), Trading blocs (pp. 3-32). Cambridge, MA: MIT Press.

Bhagwati, J. (2008). Termites in the trading system. New York, NY: Oxford University Press.

Bluestone, B., \& Harrison, B. (2000). Growing prosperity. New York, NY: Houghton Mifflin.

Bollen, K. A., \& Appold, S. J. (1993). National industrial structure and the global system. American Sociological Review, 58, 283-301.

Bornschier, V., \& Chase-Dunn, C. (1985). Transnational corporations and underdevelopment. New York, NY: Praeger.

Brady, D., \& Denniston, R. (2006). Economic globalization, industrialization and deindustrialization in affluent democracies, 1960-2001. Social Forces, 85, 297-329.

Bunker, S. G. (1985). Underdeveloping the Amazon. Chicago, IL: University of Chicago Press.

Cardenas, E., Ocampo, J. A., \& Thorp, R. (2000). An economic history of twentiethcentury Latin America, Volume 3: Industrialization and the state in Latin America: The postwar years. New York, NY: Palgrave.

Cardoso, F., \& Faletto, E. (1979). Dependency and development in Latin America. Berkeley: University of California Press.

Cavalcanti, H. B. (2002). Sociology of work in Latin America: Notes from a dynamic discipline. Work and Occupations, 29, 5-31.

Centeno, M. A. (2002). Blood and debt. State College: Pennsylvania State University Press.

Chase-Dunn, C., \& Grimes, P. (1995). World-systems analysis. Annual Review of Sociology, 21, 387-417.

Chibber, V. (2003). Locked in place: State building and late industrialization in India. Princeton, NJ: Princeton University Press.

Chinn, M. D., \& Ito, H. (2008). A new measure of financial openness. Journal of Comparative Policy Analysis, 10, 309-322.

Clark, C. (1957). The conditions of economic progress. London, UK: Macmillan. (Original work published 1940)

Collier, P. (2007). The bottom billion. New York, NY: Oxford University Press.

Dasgupta, S., \& Singh, A. (2006). Manufacturing, services and premature deindustrialization in developing countries (Research Paper No. 2006/49). Helsinki, Finland: United Nations University-World Institute for Development Economics.

De La Garza Toledo, E. (2007). The crisis of the maquiladora model in Mexico. Work and Occupations, 34, 399-429. 
Dodzin, S., \& Vamvakidis, A. (1999). Trade and industrialization in developing agricultural economies (IMF Working Paper, WP/99/145). Washington, DC: International Monetary Fund.

Economic Commission of Latin America. (Various Years). Statistical yearbook for Latin America and the Caribbean: Economic commission of Latin America. Santiago, Chile: United Nations Publication.

Evans, P. (1979). Dependent development. Princeton, NJ: Princeton University Press. Evans, P. (1995). Embedded autonomy. Princeton, NJ: Princeton University Press.

Evans, P., \& Rauch, J. E. (1999). Bureaucracy and growth: A cross-national analysis of the effects of "Weberian" state structures on economic growth. American Sociological Review, 64, 748-765.

Evans, P. B., \& Timberlake, M. (1980). Dependence, inequality, and the growth of the tertiary: A comparative analysis of less developed countries. American Sociological Review, 45, 531-552.

Firebaugh, G. (1992). Growth effects of foreign and domestic investment. American Journal of Sociology, 98, 105-130.

Firebaugh, G. (2003). The new geography of global income inequality. Cambridge, MA: Harvard University Press.

Fligstein, N. (2001). The architecture of markets. Princeton, NJ: Princeton University Press.

Fligstein, N. (2005). The political and economic sociology of international economic arrangements. In N. J. Smelser \& R. Swedberg (Eds.), The handbook of economic sociology (2nd ed., pp. 183-204). Princeton, NJ: Princeton University Press.

Frank, A. G. (1969). Capitalism and underdevelopment in Latin America. New York, NY: Monthly Review Press.

Frieden, J. (2006). Global capitalism. New York, NY: Norton.

Gallagher, K. P., Moreno-Brid, J. C., \& Porzecanski, R. (2008). The dynamism of Mexican exports: Lost in (Chinese) translation? World Development, 36, 1365-1380.

Gereffi, G., Spener, D., \& Bair, J. (2002). Free trade and uneven development. Philadelphia, PA: Temple University Press.

Gereffi, G., \& Wyman, D. (1990). Manufacturing miracles. Princeton, NJ: Princeton University Press.

Gilpin, R. (2001). Global political economy. Princeton, NJ: Princeton University Press. Grant, D. S., II, \& Wallace, M. (1994). The political economy of manufacturing growth and decline across the American states, 1970-1985. Social Forces, 73, 33-63.

Guillén, M. F. (2001). The limits of convergence. Princeton, NJ: Princeton University Press.

Harvey, D. (2005). A brief history of neoliberalism. New York, NY: Oxford University Press. 
Hirschman, A. O. (1958). The strategy of economic development. New Haven, CT: Yale University Press.

Hirschman, A. O. (1968). The political economy of import-substituting industrialization in Latin America. Quarterly Journal of Economics, 82, 1-32.

Hooks, G., \& Bloomquist, L. E. (1992). The legacy of World War II for regional growth and decline: The cumulative effects of wartime investments on U.S. manufacturing, 1947-1972. Social Forces, 71, 303-337.

International Labour Organization. (2010). International Labour Organization LABORSTA Database. Retrieved http://laborsta.ilo.org/

International Monetary Fund. (Various Years-a). International financial statistics. Washington, DC: Author.

International Monetary Fund. (Various Years-b). Direction of trade statistics. Washington, DC: Author.

Jorgenson, A., Dick, C., \& Mahutga, M. C. (2007). Foreign investment dependence and the environment: An ecostructural approach. Social Problems, 54, 371-394.

Kaya, Y. (2010). Globalization and industrialization in 64 developing countries, 1980-2003. Social Forces, 88, 1153-1182.

Kenney, M., Goe, W. R., Contreras, O., Romero, J., \& Bustos, M. (1998). Learning factories or reproduction factories? Labor-management relations in the Japanese consumer electronics maquiladoras in Mexico. Work and Occupations, 25, 269-304.

Kentor, J., \& Boswell, T. (2003). Foreign capital dependence and development: A new direction. American Sociological Review, 68, 301-313.

Kentor, J., \& Kick, E. (2008). Bringing the military back in: Military expenditures and economic growth 1990 to 2003. Journal of World-Systems Research, 14, 142-172.

Kerr, C., Dunlop, J. T., Harbison, F., \& Myers, C. A. (1960). Industrialism and industrial man. Cambridge, MA: Harvard University Press.

Kollmeyer, C. (2009). Explaining deindustrialization: How affluence, productivity growth, and globalization diminish manufacturing employment. American Journal of Sociology, 114, 1644-1674.

Levy, M. J., Jr. (1966). Modernization and the structure of society. Princeton, NJ: Princeton University Press.

Londero, E., \& Teitel, S. (1998). Resources, industrialization and exports in Latin America. New York, NY: St. Martin's.

London, B., \& Smith, D. A. (1988). Urban bias, dependence, and economic stagnation in noncore nations. American Sociological Review, 53, 454-463.

Marshall, M. G., Jaggers, K., \& Gurr, T. R. (2005). Polity IV dataset. College Park, MD: Center for International Development and Conflict. 
Martin, N., \& Brady, D. (2007). Workers of the less developed world unite? A multilevel analysis of unionization in less developed countries. American Sociological Review, 72, 562-584.

Midford, P. (1993). International trade and domestic politics: Improving on Rogowski's model of political alignments. International Organization, 47, 535-564.

Moore, W. E. (1965). The impact of industry. Englewood Cliffs, NJ: Prentice-Hall.

Moreira, M. M. (2007). Fear of China: Is there a future for manufacturing in Latin America? World Development, 35, 355-376.

O’Donnell, G. (1973). Modernization and bureaucratic-authoritarianism. Berkeley, CA: Institute of International Studies.

Paus, E. A., \& Gallagher, K. P. (2008). Missing links: Foreign investment and industrial development in Costa Rica and Mexico. Studies in Comparative International Development, 43, 53-80.

Phillips, N. (2004). The southern cone model. New York, NY: Routledge.

Pieper, U. (2000). Deindustrialization and the social economic sustainability nexus in developing countries: Cross-country evidence on productivity and employment. Journal of Development Studies, 36, 66-99.

Portes, A., \& Hoffman, K. (2003). Latin American class structures: Their composition and change during the Neoliberal Era. Latin American Research Review, 38, 41-82.

Portes, A., \& Roberts, B. S. (2005). The free-market city: Latin American urbanization in the years of the neoliberal experiment. Studies in Comparative International Development, 40, 43-82.

Robinson, R. V., \& Briggs, C. M. (1991). The rise of factories in nineteenth-century Indianapolis. American Journal of Sociology, 97, 622-656.

Rosen, E. I. (2002). Making sweatshops. Berkeley: University of California Press.

Rowthorn, R., \& Wells, J. R. (1987). De-industrialization and foreign trade. New York, NY: Cambridge University Press.

Schiff, M., \& Winters, L. A. (2003). Regional integration and development. Washington, DC: The World Bank and Oxford University Press.

Schoonmaker, S. (1995). High-tech development politics: New strategies and persistent structures in Brazilian informatics. Sociological Quarterly, 36, 369-395.

Schrank, A. (2004). Ready-to-wear development? Foreign investment, technology transfer, and learning by watching in the apparel trade. Social Forces, 83, 123-156.

Schrank, A. (2008). Homeward bound? Interest, identity, and investor behavior in a third world export platform. American Journal of Sociology, 114, 1-34.

Schurman, R. A. (2001). Uncertain gains: Labor in Chile's new export sectors. Latin American Research Review, 36, 3-29.

Schwartzman, K. C. (1995). The historical and global nature of dependent development: A time-series analysis of Brazil and Mexico. Review, 18, 589-631. 
Stockholm International Peace Research Institute. (Various Years). Armaments, disarmament and international security: Stockholm International Peace Research Institute yearbook. New York, NY: Oxford University Press.

Stiglitz, J. E. (2002). Globalization and its discontents. New York, NY: Norton.

United Nations Commission on Trade and Development. (2008). FDI database. Retrieved from http://unctadstat.unctad.org/ReportFolders/reportFolders.aspx?sCS _referer=\&sCS_ChosenLang=en

Vreeland, J. (2003). The IMF and economic development. New York, NY: Cambridge University Press.

Wallerstein, I. (1974). The modern world-system, vol. 1: Capitalist agriculture and the origin of the European world-economy in the sixteenth century. New York, NY: Academic Press.

World Bank. (2010). World development indicators online: World Bank. Retrieved from http://databank.worldbank.org/ddp/home.do?Step=12\&id=4\&CNO=2

Winship, C., \& Morgan, S. L. (1999). The estimation of causal effects from observational data. Annual Review of Sociology, 25, 259-706.

Wolf, M. (2004). Why globalization works. New Haven, CT: Yale University Press.

Wood, A. (1994). North-South trade, employment and inequality. Oxford, UK: Clarendon.

Wooldridge, J. M. (2003). Introduction to econometrics. Cambridge, MA: MIT Press.

\section{Bios}

David Brady is associate professor of sociology and public policy at Duke University, Durham, North Carolina. He studies poverty/inequality, politics, comparative political economy, social policy, globalization, labor/work, and economic sociology. His book Rich Democracies, Poor People was published by Oxford University Press in 2009.

Yunus Kaya is an assistant professor of sociology at the University of North Carolina Wilmington. He received his $\mathrm{PhD}$ degree from Duke University. His research focuses on globalization, development, global inequalities, labor, and social class. He recently published an article in the Social Forces analyzing the impact of globalization on industrialization in 64 developing countries.

Gary Gereffi is professor of sociology and director of the Center on Globalization, Governance \& Competitiveness at Duke University. His books include The New Offshoring of Jobs and Global Development (International Institute of Labor Studies, 2006) and Global Value Chains in a Postcrisis World: A Development Perspective (The World Bank, 2010). 